\begin{tabular}{|c|ccc|c|}
\hline & PORT SAID ENGINEERING RESEARCH JOURNAL \\
\hline
\end{tabular}

\title{
A Comparative Study of Integrated Coal Gasification Combined- Cycle Power Plants (ICGCC) with Kalina Cycle
}

\begin{abstract}
:
Okeily M.A ${ }^{1}$, Mikhael, N.N ${ }^{2}$, K.A. Morad ${ }^{3}$ and A.M.I.Mohamed ${ }^{4}$

Low grade waste heat utilization and new combustion technology are challenging tasks for researchers to achieve these objectives. This paper is concerned with the integration of coal gasification system with a combined gas turbine, steam turbine power plant cycles and with ammonia-water cycle, which is known as Kalina cycle. Al-maghara coal in North Sinai is used as the solid fuel in gasification process. Three cycles configurationsare compared as follows: Scheme (A) with dual pressure Heat recovery boiler with the condenser of steam cycle as the evaporator for Kalina cycle,scheme (B) with heat recovery boiler for both of steam and Kalina cycleand scheme (C), similar to scheme (A), but with a superheating in Kalina cycleto identify the most promising one for implementation. Key parameters of Kalina cycle were the main elements of comparison. Results revealed that scheme (A) has the best performance with regard to the output power, thermal efficiency and specific fuel consumption. Substantially, the integration of Kalina cycle with coal gasification combined cycle counterbalances the reduction of the overall efficiency due to the gasification thermal efficiency. Therefore, integration of Kalina cycle in the ICGCC is justified.Furthermore, part load calculations were made for scheme (A) and identified that the integration of Kalina cycle to ICGCC imposed restrictions to Kalina cycle constrains, so that it is more economical to keep such configuration of combined plants at nearly full load conditions.
\end{abstract}

\section{INTRODUCTION}

Energy is the lifeblood of societies.Although new power generation methods such as solar and wind power generation have been in the headlines over the past few years, thermal power stations burning fossil fuels such as coal, natural gas and oil still satisfy over $60 \%$ of electricity demand.The main reasons for using thermal power generation as the mainstay of supply are: the ability to cope with variability in electricity demand throughout the day and seasonal variability; and the reasonable generation costs.

Waste heat to power (WHP) is the process of capturing heat discarded by an existing industrial process and using that heat to generate power. Energyintensive industrial processes release hot exhaust gases and waste streams that can be harnessed with wellestablished technology to generate electricity.

One of the reasons that low temperature waste heat has become an interesting area is that no process is completely efficient, due to irreversibilities in the process. With the advancement of technology, there is greater interest in designing an efficient, reliable, and cost-effective energy conversion system that will supply a utilized way of low temperature heat source which may not otherwise be exploited.

${ }^{T}$ Mechanical Power Engineering Dept., Faculty of Engineering, Port Said University, Portsaid, Egypt, E-mail: Encomma5@yahoo.com ${ }^{2}$ Mechanical Power Engineering Dept., Faculty of Engineering, Port Said University, Portsaid, Egypt, E-mail: nadvmikhael@ymail.com ${ }^{3}$ Mechanical Power Engineering Dept., Faculty of Engineering, Port Said University, Port Said, Egypt,E-mail:

kamalmorad2002@yahoo.com

${ }^{4}$ Mechanical Power Engineering Dept., Faculty of Engineering, Port Said University, Portsaid, Egypt, E-mail: mohamed.av@gmail.com
In early 1980s the Russian engineer Alexander Kalina invented a new family of thermodynamic power cycles using ammonia-water mixture as the working fluid and this kind of cycle configuration was named (Kalina cycle) [1].

He discussed the Kalina cycle and the benefits of replacement of Rankine cycle with the modified one as a bottoming cycle. Several combined power systems based on this cycle have been designed and well calculated. The efficiency of this cycle is from 1.6 to 1.9 times higher than that of the Rankine cycle system, at the same conditions. The cost per unit of power output for this cycle is lower than that for the Rankine cycle system in approximately direct proportion to the energy advantage.

With the utilization of a non-azeotropic mixture, the change in temperature during the boiling and condensation of the mixture will result. Due to this, a closer match in temperature profile between the heat source and the working fluid is achieved compared with steam-based cycle, where boiling essentially happens at constant pressure and temperature and does not have a good match with the temperature profiles.

Various papers [2-4] reveal the advantage of ammonia-water mixture for power generation by using low grade heat source very efficiently.

In 2003, Jonsson [5] investigated the kalina cycles as bottoming processes for natural gas-fired gas and gas diesel engines. It was shown that the Kalina cycle has a better thermodynamic performance than the steam Rankine cycle for this application.

The adoption of the Kalina cycle to a certain heat source and a certain cooling fluid sink has one degree of freedom more than the Organic Rankine Cycle 
(ORC), as the ammonia-water composition can be adjusted as well as the system high and low pressure levels [6]. Therefore, Comparing with ORC, the Kalina cycle system 11 [2] (KCS11) has better overall performance at moderate pressures for low-temperature geothermal heat sources [7].

Murugan and Subbarao[8]studied a new methodology proposed for the utilization of various low grade steam in ammonia-water cycle to obtain a better power output and higher plant efficiency. The suggested ammonia-water cycle that utilizes low-grade steam produces higher-power output and it is more efficient than the Rankine steam cycle utilizing the low-grade steam and operates on a condensing mode. Results showed that $14.7 \%$ more power output and 2.1 $\%$ more efficient for the same heat input for ammoniawater cycles relative to Rankine cycle plants operating on a condensing mode at the optimized condition could be reached.

Marston et al. [9] made a comparison of the performance of both triple-pressure steam cycle and a single-stage Kalina cycle of his simplified mode [3] and an optimized three-stage Kalina cycle as the bottoming sections of a gas turbine combined cycle power plant. Results showed that both Kalina cycles were more efficient than the triple pressure steam cycle.

In the present work, a comparison using the Kalina cycle key parameters is carried out for evaluating the performance of three proposed combined cycles. These cycles are mentioned in three schemes (A-C) as: Scheme (A) of Dual-pressure boiler cascaded gasturbine/ Rankine/ Kalina combined cycle (CACC), Scheme (B) of a single pressure shared boiler regenerative Rankine/Kalina combined cycle with gas turbine (SBCC), and scheme (C) of a single pressure boiler cascaded combined cycle with a superheating in Kalina (CACSC). The comparative study of the three schemes aims at identifying the most promising cycle configurations and cyclesconstraints.

A thermodynamic analysis has been done on the all cycles and the calculations of overall and combined thermal efficiencies plus the output shaft powers has been established. In addition to the evaluation of (HRB), exergy efficiency is made and (T-Q) diagram for energy saving is drawn.

\section{Plants Layout and design constrains}

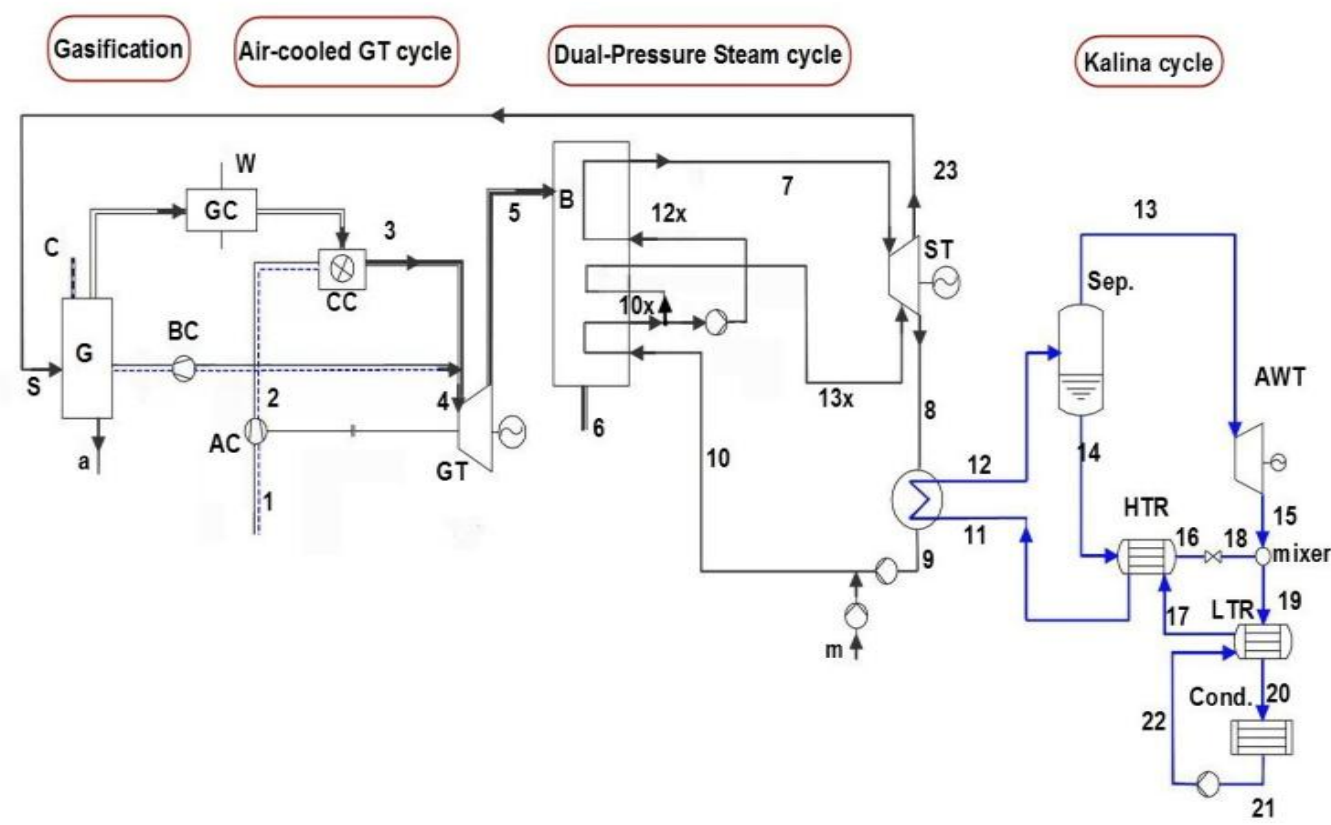

Fig. 1: Scheme(A) - (CACC)- Cascaded combined cycle 


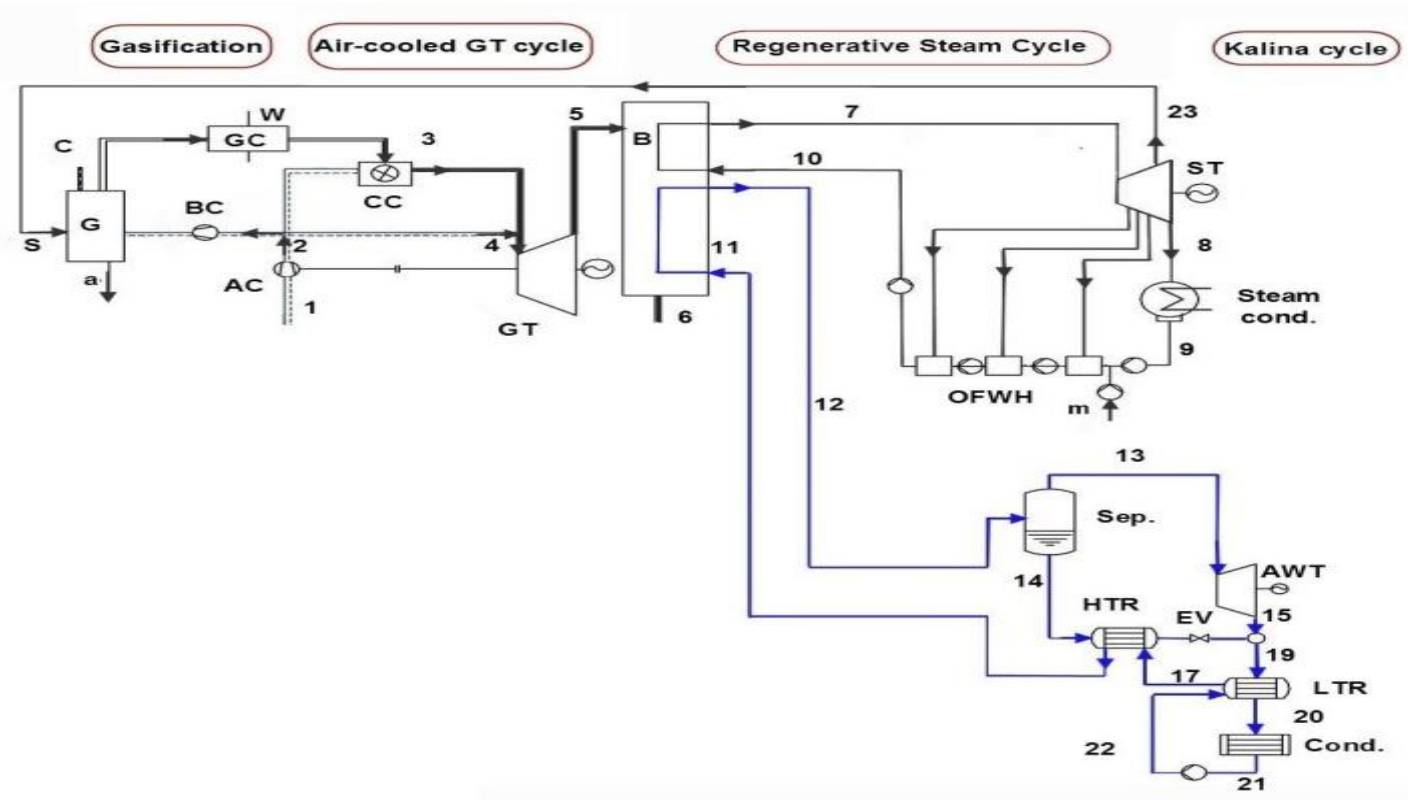

Fig.2: Scheme(B) - (SBCC)- shared boiler combined cycle

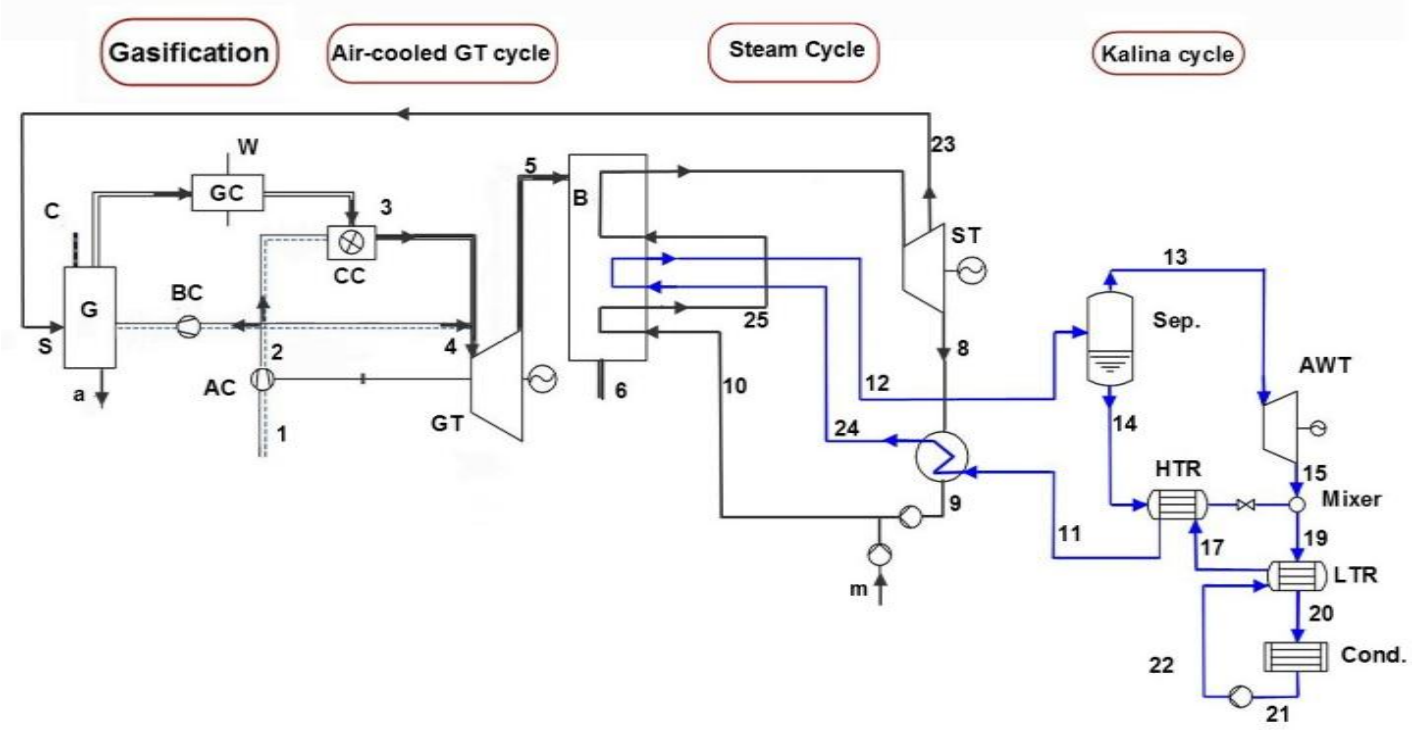

Fig.3: Scheme (C) - (CACSC)-cascaded combined cycle with a superheating in Kalinacycle

All proposed cycles are shown in Figs. (13). Theintegration of the first cycle of scheme (A) is described in Fig.1. Air cooled simple gas turbine cycle fuelled by Sinai's Al-Maghara coal gas resulted from a fixed bed gasification system is introduced in all the three schemes.

A Rankine cycle with a dual pressure heat recovery boiler is used for steam generation, and a Kalina cycle of Murugan model [8] is the bottoming cycle for the integration.

The second cycle of scheme (B) depends on a shared heat recovery boiler as the heat source for a regenerative Rankine cycle comprising three open type feed water heatersand Kalina cycle of the same Model of Murugan and subbarao [4] as shown in Fig.2.
A modification to scheme (A) is appeared in Fig.3 of scheme (C). The difference here is, that the cycle is working on a single pressure heat recovery boiler and there is a superheating of the ammonia-water mixture which comes out of the steam condenser (evaporator of Kalina cycle) before entering the separator.

Al-Maghara coal is a high volatile, low rank subbituminous perhydrous coal (which contains more than $6 \%$ hydrogen) with a calorific value of $7422 \mathrm{cal} / \mathrm{g}$ [10], the ultimate and proximate analyses of which are given in Table 1.

The integration of the gasification system with combined cycle power plant is supported by the fact that the required gasifying air and gasifying steam are then available from the gas turbine (GT) plant and steam turbine (ST) plant, respectively. The make-up 
water must be used to counterbalance the fraction of steam required for the gasifier.

Table 1: The ultimate and proximate analyses of Almaghara coal [10]

\begin{tabular}{|l|c|}
\hline Parameters & Fresh coal sample (FC) (\%) \\
\hline Carbon & 72.04 \\
\hline Hydrogen & 6.62 \\
\hline Oxygen & 13.3 \\
\hline Nitrogen & 2.27 \\
\hline Sulphur (organic) & 5.77 \\
\hline
\end{tabular}

\begin{tabular}{|l|c|}
\hline Para meters & Fresh coal sample (FC) (\%) \\
\hline Ash & 6.12 \\
\hline Moisture & 2.65 \\
\hline Fixed carbon & 40.63 \\
\hline Volatile & 50.6 \\
\hline
\end{tabular}

Furthermore, the fuel product gas is treated and free from particulates and corrosives. Steps of fuel gas production are described in Fig.4 which consists of two stages: gas generator and gas treatment. Further details about gasification can be found in $[11,12]$

To provide a base for comparison between the different plants, certain boundary conditions were kept constant such as compressor and gas turbine pressure ratio, in let gas turbine and stack gas temperatures, live steam pressure and temperature, and the isentropic efficiency of steam turbine and pump, respectively.

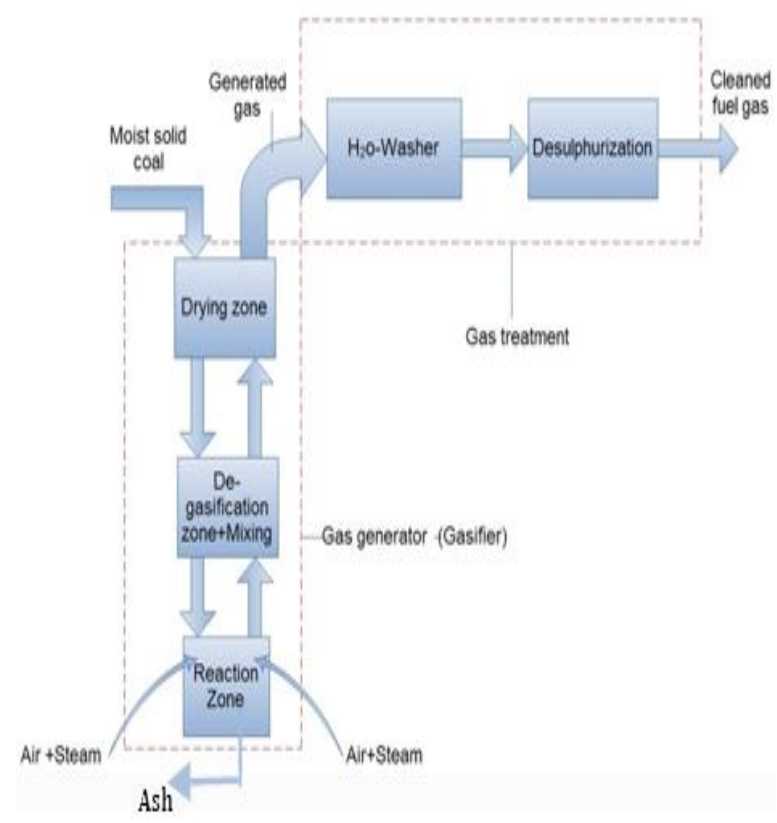

Fig. 4 : Steps of coal gas production

\section{Thermodynamic Analysis, Solution Technique, and Validation}

The following analysis are considered neglecting the mechanical generator losses, the power required to drive the booster compressor and the auxiliaries of the plant, the heat and other losses assuming there is no losses in combustion chamber.

\subsection{Gas Turbine Plant (GT)}

This unit is identical in all the three schemes (A, B, C). For all the plants, the unit is an air cooled simple gas turbine cycle as shown in Fig.5.

Part of compressed air $\left(\mu_{1}\right)$ goes for cooling the high temperature combustible gases before entering the gas turbine and the other part goes for gasifier as a gasification air $\left(\mu_{2}\right)$.

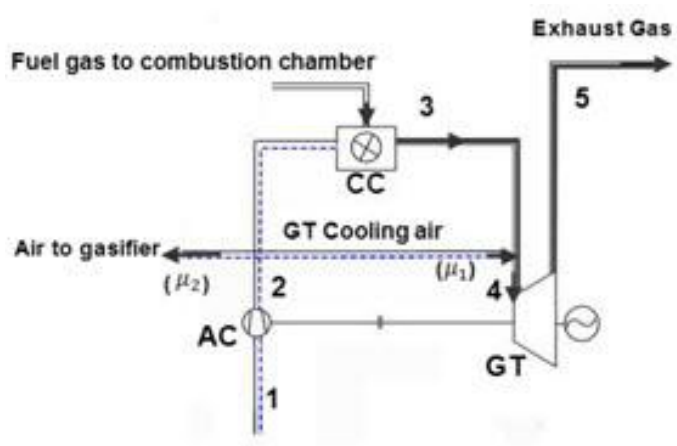

Fig. 5: A ir cooled GT cycle

There are some fixed assumed data such as: Inlet pressure and temperature $(\mathrm{p} 1, \mathrm{t} 1)$, total air mass flow rate in $\mathrm{kg} / \mathrm{s}$, cooling air flow rate in $\mathrm{kg} / \mathrm{s}$, compressor and turbine pressure ratio, combustion chamber final temperature, compressor and turbine polytropic efficiencies and ignoring the heat loss in combustion chamber and neglecting the pressure drop in pipe lines.

The fraction of cooling air for the gas turbine is taken as 0.05 of the exhaust gas flow as reported in [13] assuming a single step cooling and then the calculations for the cooling air flow fractions in the first (nozzle guide vane) row of the turbine based on the assumptions illustrated in Fig. 6.

The combustion temperature (Tc) and the cooling air temperature as the compressor delivery temperature (T2). The cooling air required is shown here as a fraction of the exhaust gas flow, i.e. as $\left(\frac{\psi}{1+\psi}\right)$, plotted against compressor pressure ratio and combustion temperature, where $(\psi)$ is the cooling air fraction. 


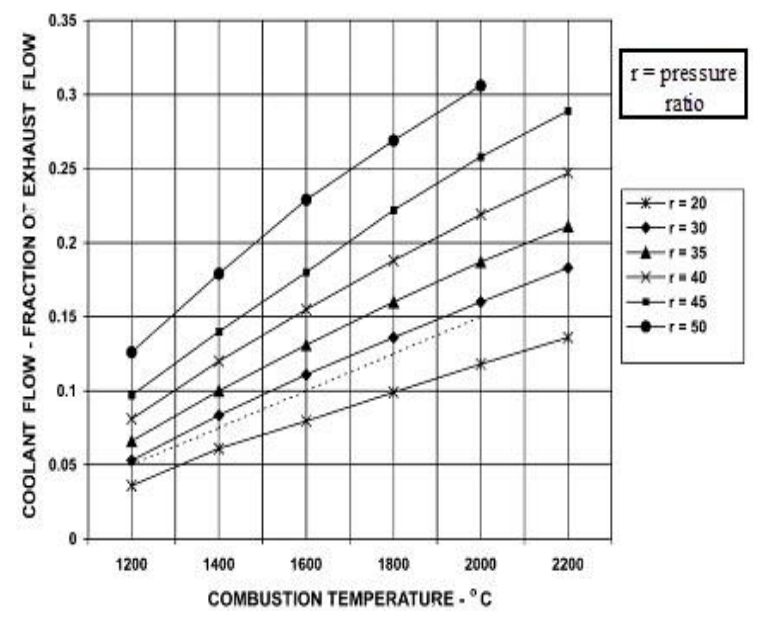

Fig.6: Calcu lated coolant air fractions for single step cooling [13]

A heat balance equation on the mixing point of cooling air is accomplished to get the inlet temperature of gas turbine $(\mathrm{t} 4)$ through:

$t_{4}=\frac{\left[\left(t_{3} \cdot c_{p_{3}} \cdot\left(1-\mu_{1}-\mu_{2}+\beta\right)+\mu_{1} \cdot c_{p_{2}} \cdot t_{2}\right)\right]}{\left[1-\mu_{2}+\beta\right]} / c_{p_{3}}$

Compressor specific work

$\left(\mathrm{w}_{\mathrm{c}}\right)=c_{p_{12}} \cdot\left(t_{2}-t_{1}\right) \quad\left(\mathrm{kJ} / \mathrm{kg}_{\mathrm{a}}\right)$

Turbine specific work

$\left(\mathrm{w}_{\mathrm{t}}\right)=c_{p_{45}} \cdot\left(1-\mu_{2}+\beta\right) \cdot\left(t_{4}-t_{5}\right)\left(\mathrm{kJ} / \mathrm{kg}_{\mathrm{a}}\right)$

where $(\beta)$ is the fuel air ratio in $\left(\mathrm{kg}_{\mathrm{f}} / \mathrm{kg}_{\mathrm{a}}\right)$, and $\left(c_{p_{12}}\right.$, $c_{p_{45}}$ ) are the specific heat for average inlet and outlet compressor and gas turbine temperatures, respectively.

The heat balance of the combustion chamber gives the heat addition in $(\mathrm{kJ} / \mathrm{kga})$

$q_{a}=\left(1-\mu_{1}-\mu_{2}+\beta\right) \cdot c_{p_{3}} \cdot t_{3}-\left(1-\mu_{1}-\mu_{2}\right) \cdot c_{p_{2}} \cdot t_{2}$ (4)

where $\left(\mathrm{c}_{\mathrm{p}_{2}}, \mathrm{c}_{\mathrm{p}_{3}}\right)$ as the specific heats at compressor and combustion chamber outlet, respectively in (kJ/kg.K)

Output power and thermal efficiency of the GT plant related to the heat input due to fuel gas are as follows:

$$
\begin{aligned}
& P_{g t}=m_{a i r} \cdot\left(w_{t}-w_{c}\right) \\
& Q_{g t}=m_{\text {air }} \cdot q_{a}(\mathrm{~kW}) \\
& \left(w_{t}-w_{c}\right) / q_{a}(7)
\end{aligned}
$$

\subsection{Heat Recovery Steam Generator (HRB) Calculations}

The recovery process will add to the efficiency of the process and thus decrease the costs of fuel and energy consumption of the combined cycle needed for that process.

The live high pressure steam generator from the HRB is chosen to be 150 bar for all schemes (A), (B), and $(\mathrm{C})$.
Scheme (A) uses a dual pressure HRB with a low pressure of 25 bar and mass flow rate equally shared between low and high pressure sections of the boiler.

Calculations of the efficiency for the boiler give:

$Q_{H R B}=m_{g} \cdot c_{p_{m g}} \cdot\left(t_{5}-t_{6}\right)$

$\eta_{\text {boiler }}=Q_{H R B} /\left(c_{p_{g}} \cdot m_{g} \cdot\left(t_{5}-t_{1}\right)\right)$

$\eta_{\text {boiler }, \text { ex }}=\left(m_{s t} \cdot\left(\mu_{4} \cdot e_{1}+e_{2}+\left(1-\mu_{4}\right) *\right.\right.$

$\left.\left.e_{3}\right)\right) /\left(m_{g} * e_{5}\right)(10)$

where $\left(\mathrm{Q}_{\mathrm{HRB}}\right)$ is the heat added to the boiler, $\left(\mathrm{m}_{\mathrm{g}}\right)$ and $\left(\mathrm{m}_{\mathrm{st}}\right)$ are the GT exhaust gas and total steam mass flow rates $(\mathrm{kg} / \mathrm{s})$, and $\left(\mathrm{c}_{\mathrm{p}_{\mathrm{g}}}\right)$ is the specific heat of the exhaust gases in (kJ/kg.k).

$\left(\mu_{4}\right)$ is the fraction of the steam for the turbine high pressure section, and (e1, e2,e3) are the specific exergy in the heat recovery boiler sections, and (e5) is the specific exergy in gas turbine.

\subsection{Rankine Cycle}

Scheme (B) works on a regenerative Rankine cycle with three open feed water heaters, unlike the other two schemes (A, C), which use a simple Rankine cycle. Asteam fraction $\left(\mu_{3}\right)$ is extracted at point (23) as a gasifying steam for the gasifer that corresponds to the specified gasifier pressure.

As seen in Fig.7, there is a low and a high pressures boiler sections in scheme (A). The low pressure boiler operates on 25 bar. The live steam pressure at (7) equals 150 bar. The turbine at this moment is divided into high and low pressure sections.

The condenser (8-9) is not working on vacuum because of the bottoming cycle (Kalina cycle) which can't operate on vacuum. A make up water fraction $\left(\mu_{3}\right)$ is supplied to recover the lost steam in gasification process.

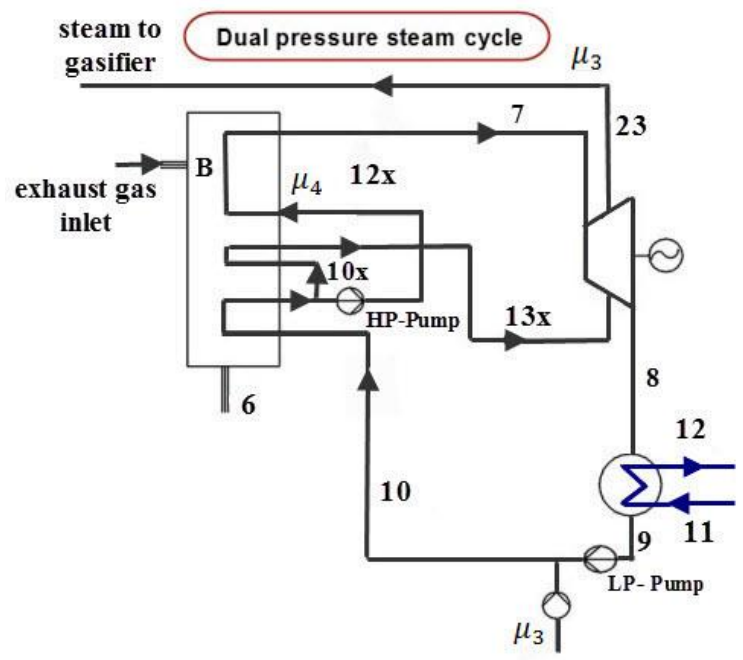

Fig. 7 : Scheme (A) - ST plant of dual pressure HRB with cascaded Kalina cycle 
Calculation of the mixing point at ST-sections as follows:

$h_{\text {mix }}=\left(1-\mu_{4}\right) \cdot h_{13 x}+\mu_{4} \cdot h_{13 x x}(11)$

where $\left(\mathrm{h}_{13 \mathrm{xx}}\right)$ is the enthalpy of the steam after expansion in the HP-turbine section.

Turbine specific work

$$
\begin{gathered}
w_{s t}=\mu_{4} \cdot\left(h_{7}-h_{\text {mix }}\right)+\left(h_{\text {mix }}-h_{8}\right)-\mu_{3} \cdot\left(h_{23}\right. \\
\left.-h_{8}\right)
\end{gathered}
$$

(12)

Net work,output power and thermal efficiency calculations

$w_{\text {net }}$ st,total $=w_{s t}-w_{H P}-w_{L P}(13)$

where $\left(\mathrm{w}_{\mathrm{LP}}\right)(9-10)$ and $\left(\mathrm{w}_{\mathrm{HP}}\right)(10 \mathrm{x}-12 \mathrm{x})$ are the work of the low and high pressure pumps, respectively.

$P_{s t}=m_{s t} \cdot w_{n e t}$ st,total

$q_{\text {st, total }}=\mu_{4} \cdot\left(h_{7}-h_{12 x}\right)+\left(h_{10 x}-h_{10}\right)+(1-$

$\left.\mu_{4}\right) \cdot\left(h_{13 x}-h_{10 x}\right)$

$\eta_{s t}=w_{\text {net }{ }_{s t, t o t a l}} / q_{s t, \text { total }}(16)$

Scheme (B) uses a regenerative Rankine cycle with three open feed water heaters as shown in Fig.8. The condenser (8-9) is working on vacuum because there is no bottoming cycle (Kalina cycle) which can't operate on vacuum.

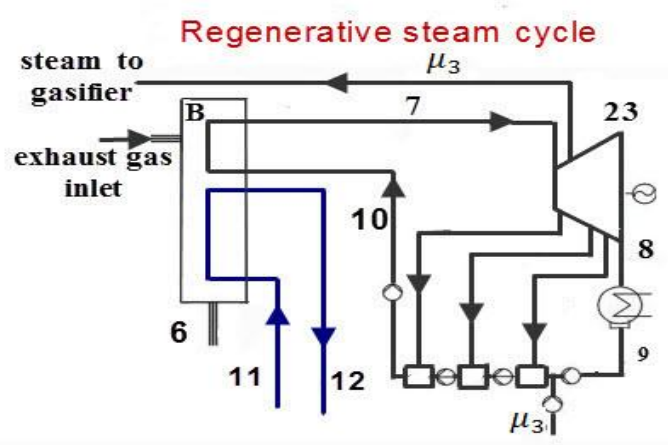

Fig.8: Scheme (B) - ST plant with shared HRB for Kalina cycle

Output power and thermal efficiency calculations

$w_{\text {net }}{ }_{\text {st total }}=w_{\text {net }, \text { st }}+\mu_{3} \cdot\left(h_{7}-h_{23}\right)$

$$
q_{s t, \text { total }}=q_{s t}+\mu_{3} \cdot\left(h_{7}-h_{10}\right)
$$

$$
\begin{aligned}
P_{s t}=m_{s t} \cdot w_{\text {net }}{ }_{\text {st,total }}(19) & \\
& \eta_{s t}=w_{\text {net }}{ }_{\text {st,total }} / q_{s t, \text { total }}
\end{aligned}
$$

It is clearly seen in Fig.9 that the steam cycle used is a simple Rankine steam cycle and it seems the same cascaded one as scheme (A), but it works on a single pressure boiler.Make up water also is used to compensate the loss in the steam for gasification.

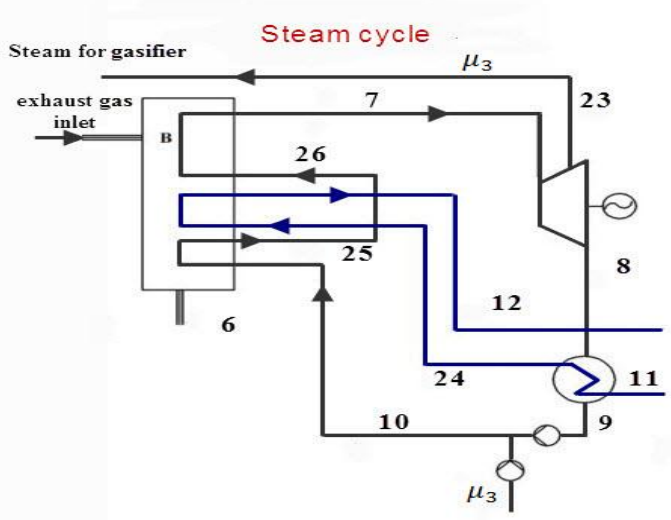

Fig.9: Scheme (C) - ST plant with cascaded Kalina cycle with superheater

Output power and thermal efficiency calculations

$$
\begin{aligned}
& w_{\text {net } \text { st,total }}=h_{7}-h_{23}+\left(1-\mu_{3}\right) \cdot\left(h_{23}-h_{8}\right) \\
& q_{s t, t \text { total }}(34) Q_{\text {st }} / m_{\dot{s} t} \\
& Q_{\text {st }}=Q_{\text {eco }}+Q_{\text {evap }}+Q_{\text {sup }}
\end{aligned}
$$

where $\left(Q_{\text {eco }}, Q_{\text {evap }}\right.$, and $\left.Q_{\text {sup }}\right)$ are the heat flow rate added to the boiler sections; economizer, evaporator and superheater.

$\eta_{s t}=w_{\text {net }}$ st,total
$P_{s t}=m_{s t, \text { total }}$

\subsection{Kalina Cycle}

The Kalina cycle is used as a bottoming cycle due to the low range temperature heat source which it can work on, but it is not only the bottoming cycle in some cases. Like scheme (B), where steam and Kalina are the bottoming cycles sharing the heat source from the exhaust gases and a little in scheme $(\mathrm{C})$, where Kalina cycle has to be superheated in the waste heat boiler and gaining some of the heat source directly although it is a bottoming cycle.

The model taken here for the three plants is Murugan and Subbarao [8] model. It has fixed points such as turbine inlet and outlet pressure and concentration, evaporator inlet concentration, temperature and pressure, and condenser pressure with assuming the values of the isentropic efficiencies for turbine and pump. 
The cycle components shown in Fig.10 are: separator, evaporator (high pressure condenser), high temperature recuperator (HTR), Low temperature recuperator (LTR), expansion valve, ammonia-water condenser and turbine (AWT), and feed pump.

Using this simple cycle with the three power plants made a change and affect positively on their performance. For scheme (A) Kalina cycle is used as a cascaded bottoming cycle recover energy from the simple Rankine cycle. In scheme (B) Kalina cycle is used as a bottoming cycle participating with Regenerative Rankine cycle to recover energy from the exhaust gases. In scheme (C), Kalina cycle is applied such as Scheme (A) a cascaded to Rankine cycle, but there is a little difference that the ammonia water mixture after passing through the condenser (steam/Kalina heat exchanger), itpasses through the boiler to acquire some energy from the exhaust gases before entering the separator.

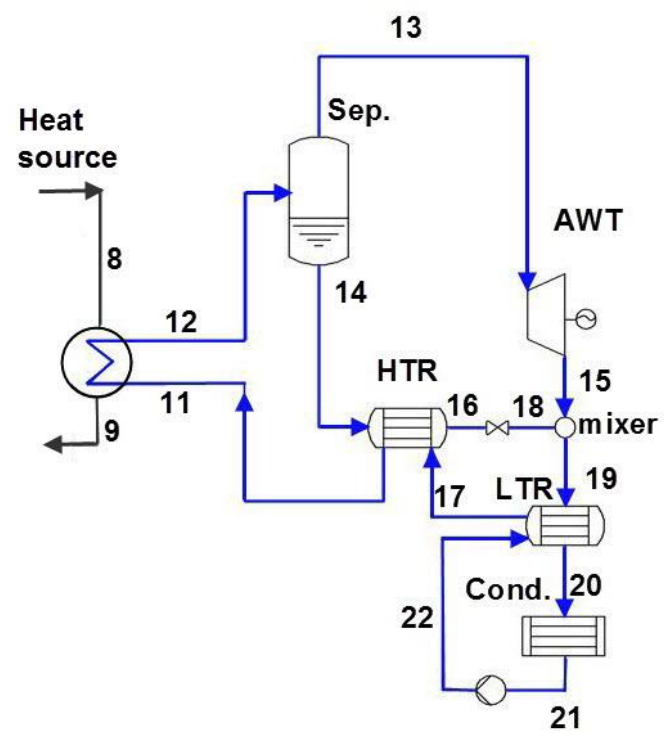

Fig. 10:Murugan and SubbaraoKalina cycle

Fig.8: Efficiency and output power calculations for Kalina cycle:

The ammonia water mixture properties are different than steam properties, so a well- organized program contains all the properties of the ammonia-water mixtu re as a package is used to get all these properties.

Heat flow rate added to Kalina cycle

$Q_{\dot{k} a}=m_{a w} \cdot\left(h_{12}-h_{11}\right)$

Turbine power

$P_{k a_{t}}=m_{13} \cdot\left(h_{13}-h_{15}\right)$

Pump output work

$P_{k a_{p}}=w_{p, \text { kalina }} \cdot m_{a w}$
Output power and thermal efficiency

$$
\begin{aligned}
& P_{k a_{\text {total }}}=P_{k a_{t}}-P_{k a_{p}} \\
& \eta_{\text {kalina }}=W_{\text {net ,Kalina }} / Q_{k a}
\end{aligned}
$$

where $\left(\mathrm{m}_{\mathrm{aw}}^{-}\right)$is ammonia water mixture mass flow rate in $(\mathrm{kg} / \mathrm{s})$.

\subsection{Combined Thermal Efficiency and}

\section{Output Power}

The three schemes (A, B, C) are using these relations to calculate the power and the thermal efficiency

$$
\begin{aligned}
P_{\text {comb }} & =P_{s t}+P_{g t}+P_{k a_{\text {total }}} \\
\eta_{\text {comb }} & =\frac{P_{c o m b}}{Q_{g t}}
\end{aligned}
$$

\subsection{Model Description and Validation}

The calculations of the gasification process are carried out with (PGI FORTRAN COMPILER) with Visual Studio Aid. The output results of these calculations are given as mathematical formulations using high regression and polynomial techniques included in EES package [14] and are used as input data for the integrated coal gasification with the different proposed combined cycles.

Also, the functions of the amount of gasifying mediums (air, steam) that is dependent on the gasifier pressure and reaction temperature which are also calculated and given as functions of the gasifier pressure. EES provides many built-in mathematical and thermo-physical property functions useful for engineering calculations like most organic refrigerants and many other fluids.In order to calculate the properties of the aqueous-ammonia working fluid, EES uses a formulation by Ibrahim and Kle in [15].

Taking the same cycle design and constrains of Murugan in Fig. 11, a validation has been made executing all the points of the Kalina cycle and considering the same heat source (steam) temperatures using ammonia-water package in EES by Ibrahim and Klein. 


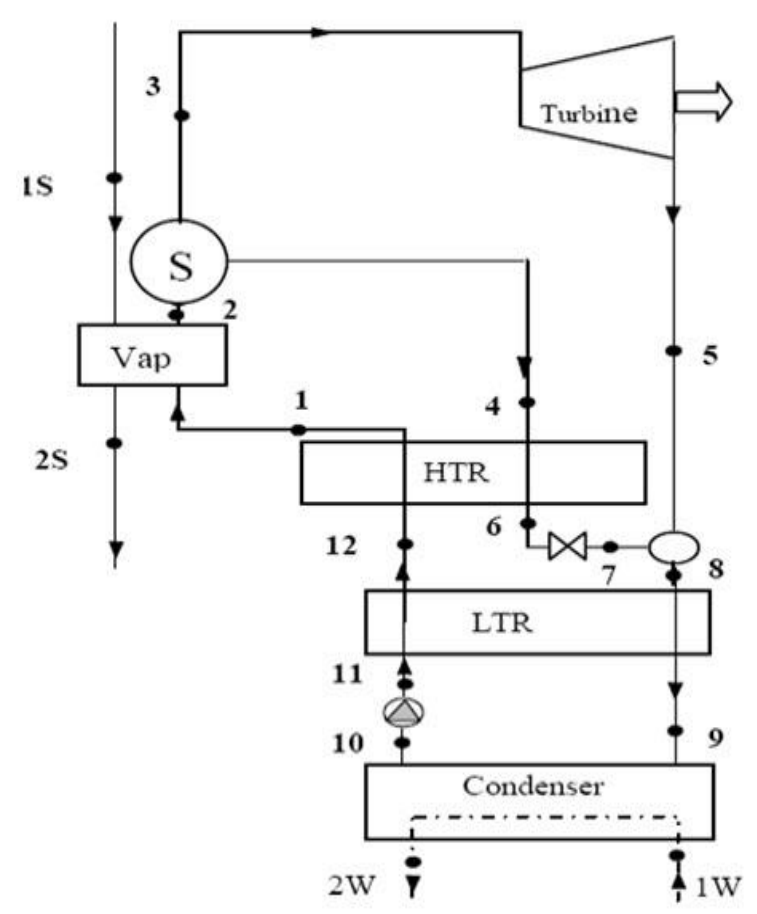

Fig.11: KalinaMurugan Cycle

As shown in Table 2 and Table 3, there is a slight variation in the values of the different points between Murugan cycle and Kalina cycle model by EES ammonia water package for all corresponding points of the cycle.

Table 2: Values obtained by Murugan and V.Subbarao [8]

\begin{tabular}{|c|c|c|c|c|c|c|}
\hline Node & $\begin{array}{c}\mathrm{P} \\
(\mathrm{bar})\end{array}$ & $\mathrm{T}^{\circ}(\mathrm{C})$ & $\begin{array}{c}\mathrm{X} \\
(\text { concent. })\end{array}$ & $\begin{array}{c}\mathrm{h} \\
(\mathrm{kJ} / \mathrm{kg})\end{array}$ & $\begin{array}{c}\mathbf{m} \\
(\mathrm{kg} / \mathrm{s})\end{array}$ & $\begin{array}{c}\mathrm{s} \\
(\mathrm{kJ} / \mathrm{kg} . \mathrm{K})\end{array}$ \\
\hline $\mathbf{1}$ & 42.52 & 47.53 & 0.89 & 147.06 & 50.51 & 0.724862 \\
\hline $\mathbf{2}$ & 41.7 & 118.5 & 0.89 & 1215.3 & 50.51 & 3.6626 \\
\hline $\mathbf{3}$ & 41.7 & 118.5 & 0.9728 & 1450.69 & 40.13 & 4.233 \\
\hline $\mathbf{4}$ & 41.7 & 118.5 & 0.5696 & 305 & 10.38 & 1.5056 \\
\hline $\mathbf{5}$ & 6.917 & 31.61 & 0.9728 & 1227.23 & 40.13 & 4.3341 \\
\hline $\mathbf{6}$ & 41.3 & 36.71 & 0.5696 & -65.30 & 10.38 & 0.3867 \\
\hline $\mathbf{7}$ & 6.917 & 37.30 & 0.5696 & -65.30 & 10.38 & 0.4007 \\
\hline $\mathbf{8}$ & 6.917 & 36.71 & 0.89 & 961.47 & 50.51 & 3.52703 \\
\hline $\mathbf{9}$ & 6.698 & 30.33 & 0.89 & 887.62 & 50.51 & 3.29694 \\
\hline $\mathbf{1 0}$ & 6.487 & 15 & 0.89 & -9.9476 & 50.51 & 0.227057 \\
\hline $\mathbf{1 1}$ & 43.33 & 15.98 & 0.89 & -3.069 & 50.51 & 0.231817 \\
\hline $\mathbf{1 2}$ & 42.93 & 31.71 & 0.89 & 70.77 & 50.51 & 0.480721 \\
\hline $\mathbf{1 w}$ & 10 & 1.013125 & 0 & 41.99 & 720.84 & 0.151 \\
\hline $2 \mathbf{w}$ & 25 & 1.013125 & 0 & 104.9 & 720.84 & 0.3673 \\
\hline $1 \mathbf{s}$ & 3 & 133.5 & 0 & 2720 & 25 & 6.979 \\
\hline $2 \mathbf{s}$ & 3 & 133.5 & 0 & 561.4 & 25 & 1.672 \\
\hline
\end{tabular}

Table3: Values obtained using EES-Ibrahim and Klein Package

\begin{tabular}{|c|c|c|c|c|c|c|} 
Node & $\mathrm{P}(\mathrm{bar})$ & $\mathrm{T}^{\circ}(\mathrm{C})$ & $\begin{array}{c}\mathrm{X} \\
(\text { concent. })\end{array}$ & $\begin{array}{c}\mathrm{h} \\
(\mathrm{kJ} / \mathrm{kg})\end{array}$ & $\begin{array}{c}\boldsymbol{m} \cdot \\
(\mathrm{kg} / \mathrm{s})\end{array}$ & $\begin{array}{c}\mathrm{s} \\
(\mathrm{kJ} / \mathrm{kg} . \mathrm{K})\end{array}$ \\
\hline $\mathbf{1}$ & 43 & 48 & 0.89 & 149.5 & 50.97 & 0.7322 \\
\hline $\mathbf{2}$ & 42 & 119 & 0.89 & 1200 & 50.97 & 3.622 \\
\hline $\mathbf{3}$ & 42 & 119 & 0.9728 & 1431 & 40.59 & 4.181 \\
\hline $\mathbf{4}$ & 42 & 119 & 0.5696 & 329.4 & 10.38 & 1.513 \\
\hline $\mathbf{5}$ & 7 & 31 & 0.9728 & 1222 & 40.59 & 4.295 \\
\hline $\mathbf{6}$ & 41 & 36 & 0.5696 & -68.52 & 10.38 & 0.377 \\
\hline $\mathbf{7}$ & 7 & 38 & 0.5696 & -68.52 & 10.38 & 0.3909 \\
\hline $\mathbf{8}$ & 7 & 36 & 0.89 & 959.1 & 50.97 & 3.502 \\
\hline $\mathbf{9}$ & 6.7 & 30 & 0.89 & 889.6 & 50.97 & 3.29 \\
\hline $\mathbf{1 0}$ & 6.5 & 15 & 0.89 & -16.6 & 50.97 & 0.204 \\
\hline $\mathbf{1 1}$ & 45 & 16 & 0.89 & -1.107 & 50.97 & 0.2148 \\
\hline $\mathbf{1 2}$ & 44 & 31.5 & 0.89 & 68.43 & 50.97 & 0.4726 \\
\hline $\mathbf{1 w}$ & 10 & 1.013 & 0 & 42.09 & 690 & 0.151 \\
\hline $2 \mathbf{w}$ & 26 & 1.013 & 0 & 109 & 690 & 0.3809 \\
\hline $1 \mathbf{s}$ & 3 & 133.5 & 0 & 2703 & 25 & 6.938 \\
\hline $\mathbf{2} \mathbf{s}$ & 3 & 133.5 & 0 & 561.4 & 25 & 1.671 \\
\hline
\end{tabular}

\section{Results and discussion}

Tables (4-7) give the selected design data and the results of the integrated coal gasification system combined cycle as applied for all schemes (A, B, C).

Table 4: Data and calculation results for the gas turbine cycle of the three schemes

\begin{tabular}{|c|c|c|c|}
\hline Data & $\begin{array}{l}\text { Scheme } \\
\text { (A) }\end{array}$ & $\begin{array}{l}\text { Scheme } \\
\text { (B) }\end{array}$ & $\begin{array}{l}\text { Scheme } \\
\text { (C) }\end{array}$ \\
\hline $\begin{array}{l}\text { Air mass flow } \\
\text { rate }(\mathrm{kg} / \mathrm{s})\end{array}$ & 300 & 300 & 300 \\
\hline $\begin{array}{l}\text { Compressor } \\
\text { pressure ratio }\end{array}$ & 15 & 15 & 15 \\
\hline $\begin{array}{l}\text { Combustion } \\
\text { chamber outlet } \\
\text { temperature }\left({ }^{\circ} \mathrm{C}\right)\end{array}$ & 1400 & 1400 & 1400 \\
\hline $\begin{array}{l}\text { Stack gas } \\
\text { temperature }\left({ }^{\circ} \mathrm{C}\right)\end{array}$ & 100 & 100 & 100 \\
\hline $\begin{array}{l}\text { Cooling Air mass } \\
\text { flow rate }(\mathrm{kg} / \mathrm{s})\end{array}$ & 15 & 15 & 15 \\
\hline $\begin{array}{l}\text { Compressor } \\
\text { polytropic } \\
\text { efficiency }\end{array}$ & 0.88 & 0.88 & 0.88 \\
\hline $\begin{array}{l}\text { GT-polytropic } \\
\text { efficiency }\end{array}$ & 0.9 & 0.9 & 0.9 \\
\hline $\begin{array}{l}\text { Regenerator } \\
\text { effectiveness }\end{array}$ & & & \\
\hline $\begin{array}{l}\text { Gasifier reaction } \\
\text { temperature }\left({ }^{\circ} \mathrm{C}\right)\end{array}$ & 800 & 800 & 800 \\
\hline Excess air factor & 2.857 & 2.857 & 2.857 \\
\hline
\end{tabular}


turbine cycle of the three schemes (continued)

\begin{tabular}{|l|c|c|c|}
\hline $\begin{array}{l}\text { Power of GT- } \\
\text { plant (kW) }\end{array}$ & 172315 & 172315 & 172315 \\
\hline $\begin{array}{l}\text { Thermal } \\
\text { efficiency of GT }\end{array}$ & 0.3488 & 0.3488 & 0.3488 \\
\hline $\begin{array}{l}\text { Mass flow rate of } \\
\text { gasifying air } \\
\text { (kg/s) }\end{array}$ & 33.96 & 33.96 & 33.96 \\
\hline $\begin{array}{l}\text { Mass flow rate } \\
\text { gasifying steam } \\
\text { (kg/s) }\end{array}$ & 13.35 & 13.35 & 13.35 \\
\hline $\begin{array}{l}\text { Mass flow rate of } \\
\text { solid coal (kg/s) }\end{array}$ & 16.16 & 16.16 & 16.16 \\
\hline $\begin{array}{l}\text { Gasification } \\
\text { efficiency }\end{array}$ & 0.855 & 0.855 & 0.855 \\
\hline
\end{tabular}

Table 5: Data for the Rankine cycle of the three schemes

\begin{tabular}{|c|c|c|c|}
\hline Data & $\begin{array}{l}\text { Scheme } \\
\text { (A) }\end{array}$ & $\begin{array}{l}\text { Scheme } \\
\text { (B) }\end{array}$ & $\begin{array}{l}\text { Scheme } \\
\text { (C) }\end{array}$ \\
\hline $\begin{array}{l}\text { Boiler HP section } \\
\text { pressure (bar) }\end{array}$ & 150 & 150 & 150 \\
\hline $\begin{array}{l}\text { Boiler LP section } \\
\text { pressure (bar) }\end{array}$ & 25 & & \\
\hline $\begin{array}{l}\text { Condenser pressure } \\
\text { (bar) }\end{array}$ & 2 & 0.07 & 2 \\
\hline $\begin{array}{l}\text { ST-isentropic } \\
\text { efficiency }\end{array}$ & 0.84 & 0.84 & 0.84 \\
\hline $\begin{array}{l}\text { Boiler feed water } \\
\text { temperature }\left({ }^{\circ} \mathrm{C}\right)\end{array}$ & 33.08 & 112.2 & 32.45 \\
\hline Number of FWH & 0 & 3 & 0 \\
\hline $\begin{array}{l}\text { HRSG thermal } \\
\text { efficiency }\end{array}$ & 0.8774 & 0.8774 & 0.8774 \\
\hline $\begin{array}{l}\text { HRSG Exergetic } \\
\text { efficiency }\end{array}$ & 0.7932 & 0.7306 & 0.8609 \\
\hline $\begin{array}{l}\text { Power of ST-cycle } \\
(\mathrm{kW})\end{array}$ & 44671 & 48604 & 38749 \\
\hline $\begin{array}{l}\text { Rankine thermal } \\
\text { efficiency }\end{array}$ & 0.2383 & 0.3612 & 0.2301 \\
\hline
\end{tabular}

Table 6: Data and calculation results for the Kalina cycle of the different schemes

\begin{tabular}{|l|c|c|c|}
\hline Data & $\begin{array}{c}\text { Scheme } \\
(\mathrm{A})\end{array}$ & $\begin{array}{c}\text { Scheme } \\
(\mathrm{B})\end{array}$ & $\begin{array}{c}\text { Scheme } \\
\text { (C) }\end{array}$ \\
\hline $\begin{array}{l}\text { Kalina turbine inlet } \\
\text { pressure (bar) }\end{array}$ & 41.7 & 41.7 & 41.7 \\
\hline $\begin{array}{l}\text { Kalina turbine outlet } \\
\text { pressure (bar) }\end{array}$ & 7 & 7 & 7 \\
\hline $\begin{array}{l}\text { Kalina turbine inlet } \\
\text { temperature }\left({ }^{\circ} \mathrm{C}\right)\end{array}$ & 110.2 & 110.2 & 140 \\
\hline $\begin{array}{l}\text { Fraction of ammonia } \\
\text { at separator inlet }\end{array}$ & 0.9728 & 0.9728 & 0.9728 \\
\hline $\begin{array}{l}\text { Fraction of ammonia } \\
\text { at evaporator inlet }\end{array}$ & 0.89 & 0.89 & 0.89 \\
\hline & 58758 & 21355 & 53642 \\
\hline $\begin{array}{l}\text { Power of Kalina } \\
\text { cycle (kW) }\end{array}$ & 0.40 & 0.40 & 0.40 \\
\hline $\begin{array}{l}\text { Thermal efficiency of } \\
\text { Kalina cycle }\end{array}$ & & \multicolumn{3}{|l}{} \\
\hline
\end{tabular}

Table 7: Calculation results the combined cycles of the different schemes

\begin{tabular}{|l|l|l|l|}
\hline Data & $\begin{array}{l}\text { Scheme } \\
(\mathrm{A})\end{array}$ & $\begin{array}{l}\text { Scheme } \\
(\mathrm{B})\end{array}$ & $\begin{array}{l}\text { Scheme } \\
(\mathrm{C})\end{array}$ \\
\hline $\begin{array}{l}\text { Overall } \\
\text { thermal } \\
\text { efficiency }\end{array}$ & 0.4987 & 0.4448 & 0.4803 \\
\hline $\begin{array}{l}\text { Output } \\
\text { power } \\
\mathrm{kW})\end{array}$ & 288115 & 256975 & 277323 \\
\hline $\begin{array}{l}\text { Pinch point } \\
\text { temperature } \\
\text { difference } \\
\left({ }^{\circ} \mathrm{C}\right)\end{array}$ & 43.84 & 39.63 & 18.69 \\
\hline
\end{tabular}

The following results are concerned with the parametric study for the different proposed cycles concerning the combined cycle thermal efficiency and output power.

These parameters are the basic of the comparison between the three schemes as follows:

\subsection{Pinch Point Temperature Difference}

This is simply the minimum temperature difference or temperature driving force between fluids. Pinch point is reached, where it becomes cost prohibitive to further reduce the temperature difference between the two flu ids in heat transfer process.

The (T-Q) diagrams of the three proposed combined cycles are shown in Fig.(12-14). In scheme (A), the hot fluid is the flue gasesfrom the gas turbine which enterthe HRB and the cold fluid is the water entering the HRB.

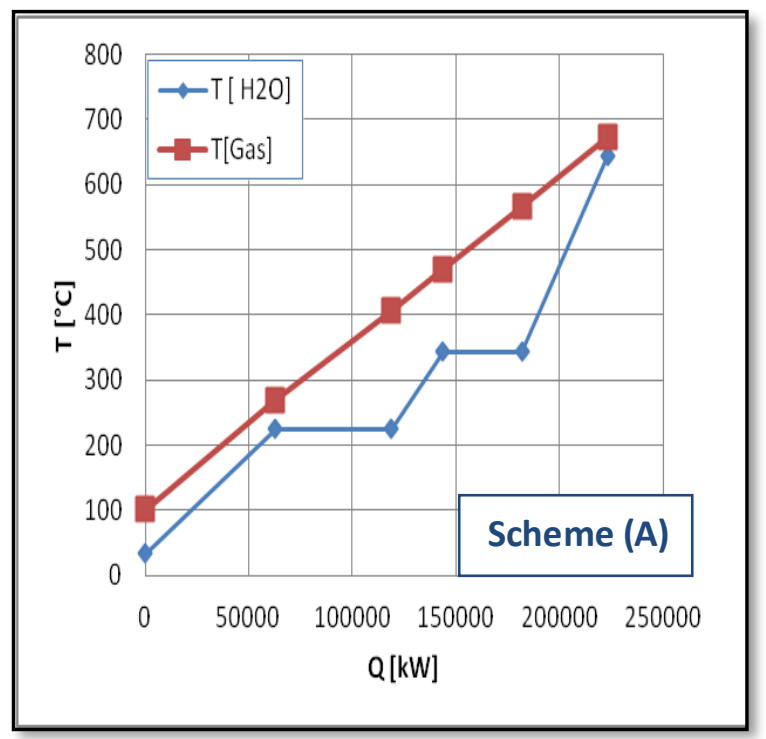

Fig.12:(T-Q) diagram for Scheme (A) 
In scheme (B), there are three fluids entering the boiler. These fluids are the flue gases, water and ammonia- water mixture.

Schemes (A) and (B) have nearly the same pinch point temperature differences. Scheme $(C)$ is the same case as scheme (A) except that superheating in Kalina cycle is taking place in the boiler. This superheating led to an improvement in pinch point temperature difference and much heat is recovered.

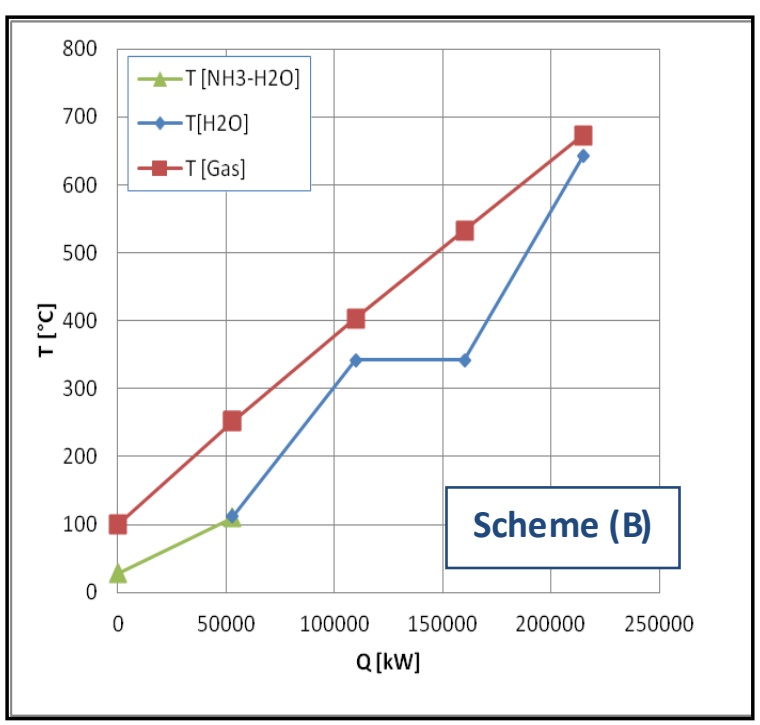

Fig. 13:(T-Q) diagram for Scheme (B)

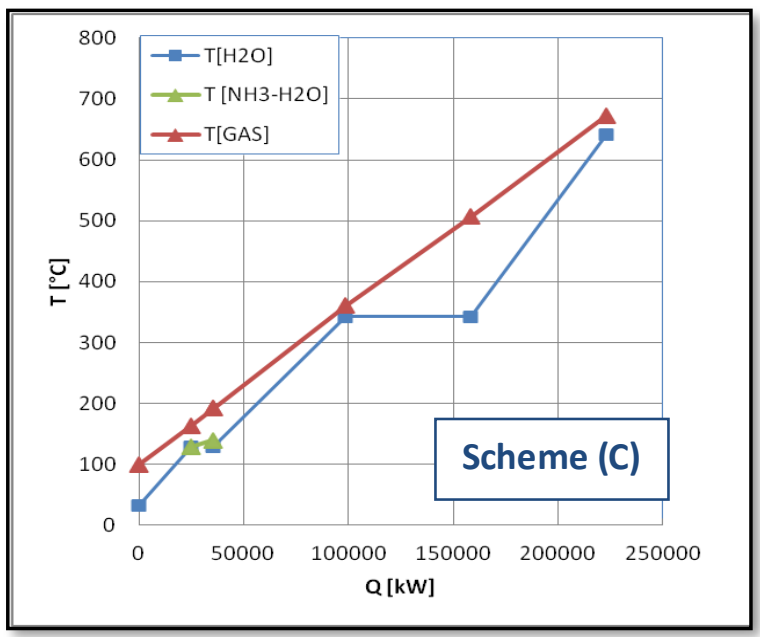

Fig. 14:(T-Q) diagram for Scheme (C)

\subsection{Effect of Ammonia-Water Turbine Inlet Pressure}

Generally, as it's shown in Figs (15-17), for the different schemes (A-C), with the increase in AW turbine inlet pressure, the net power increases. With increasing in AW turbine inlet concentration, the power decreases.This happens due to the decrease in mass flow rate of ammonia-water mixture.A slight increase happens at much richer ammonia water mixture.

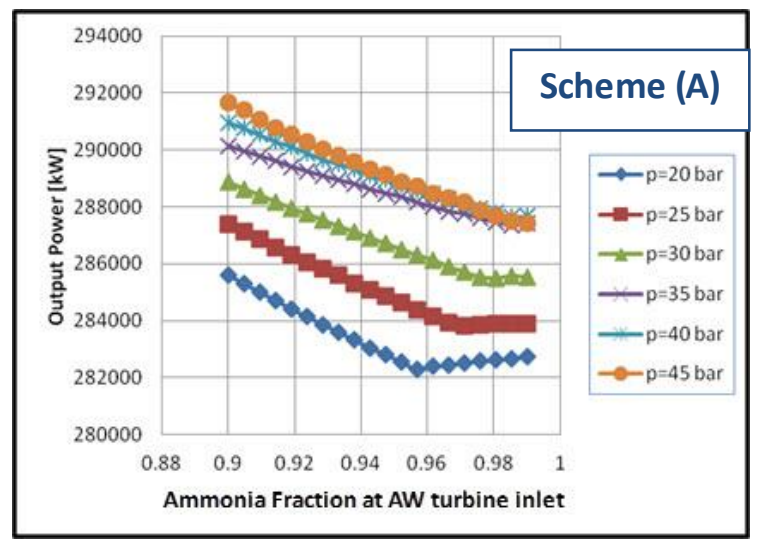

Fig. 15: Effect of ammonia fraction on the output power at different inlet pressures of $\mathrm{AW}$ turbine for scheme (A)

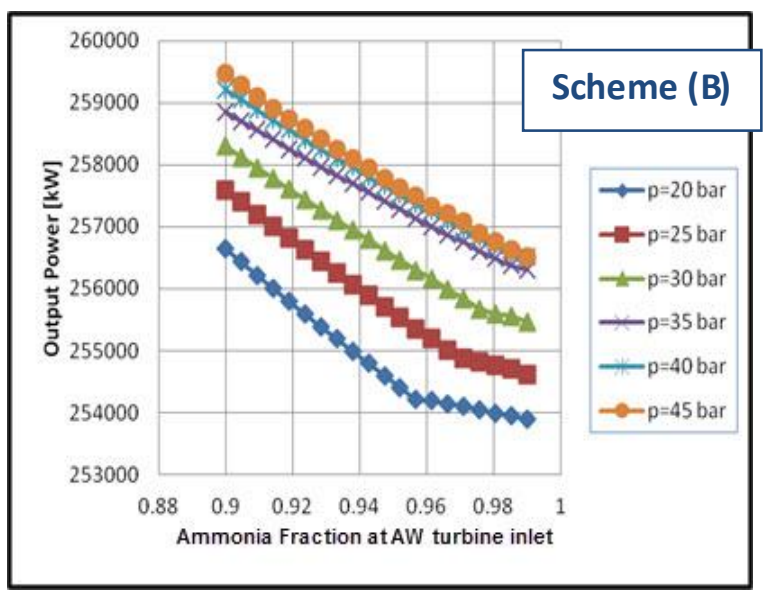

Fig. 16: Effect of ammonia fraction on the output power at different inlet pressures of AW turbine for scheme (B)

Due to superheating of ammonia-water mixture before entering the turbine in scheme (c), power and efficiency show an early increase at less richer concentrations. 
The variation of combined thermal efficiency with ammonia fraction at different turbine inlet pressures for different schemes also is described in Figs (18-20).

The thermal efficiency as shown is high at a fraction of 0.9 , and it keeps decreasing as the ammonia fraction is increased, and then slightly increased corresponding to a much richer ammonia water mixtu re.

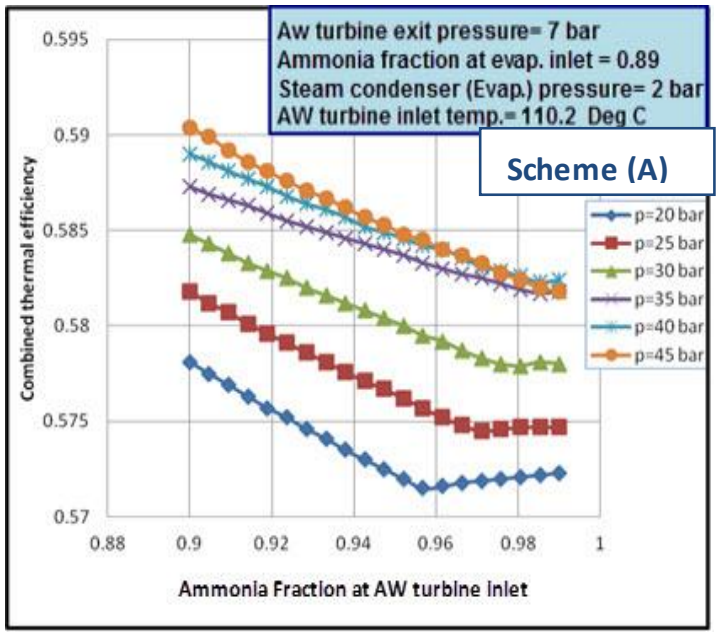

Fig. 18: Effect of ammonia fraction on the combined thermal efficiency at different inlet pressures of AW turbine for scheme (A)

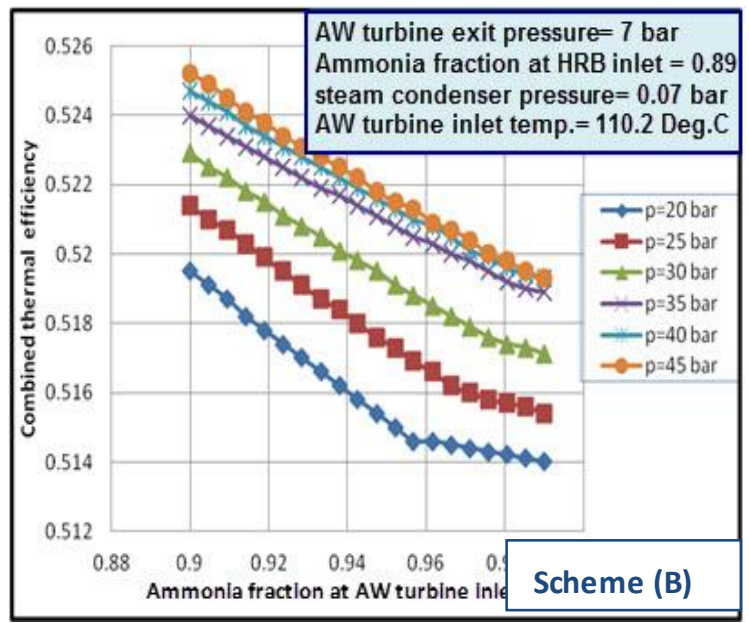

Fig.19: Effect of ammonia fraction on the combined thermal efficiency at different inlet pressures of AW turbine for scheme (B)

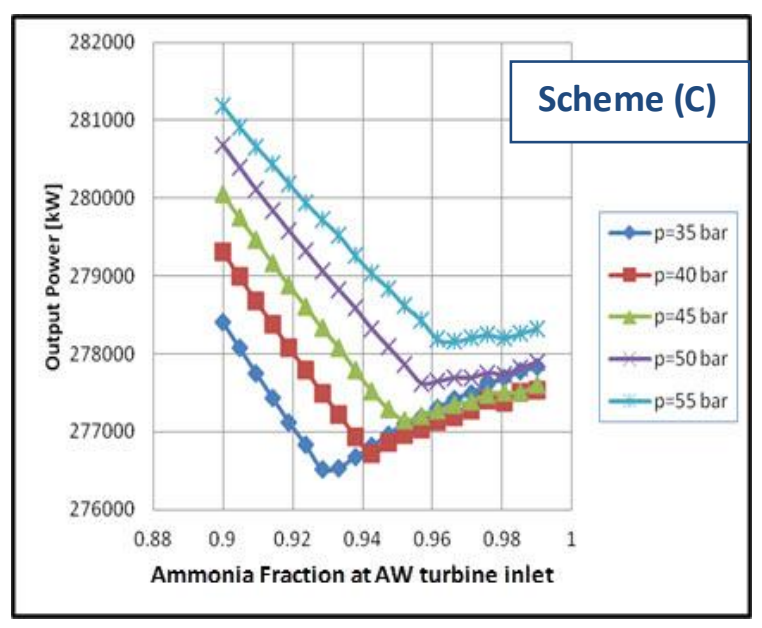

Fig. 17: Effect of ammonia fraction on the output power at different inlet pressures of $\mathrm{AW}$ turbine for scheme $(\mathrm{C})$

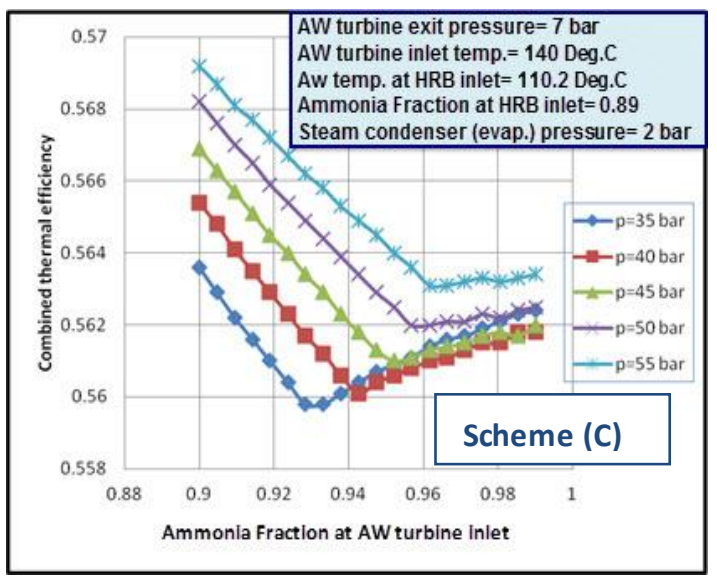

Fig. 20: Effect of ammonia fraction on the combined thermal efficiency at different inlet pressures of AW turbine for scheme $(\mathrm{C})$

\subsection{Effect of AW turbine inlet temperature}

With increasing AW turbine inlet temperature, the output power and thermal efficiency decrease then increase at some higher temperatures.

This happens due to the increase in rich ammoniawater mass flow rate entering the turbine.Figures (2123) shows the variation in output power with AW turbine inlet temperature at different turbine inlet pressures for different schemes 


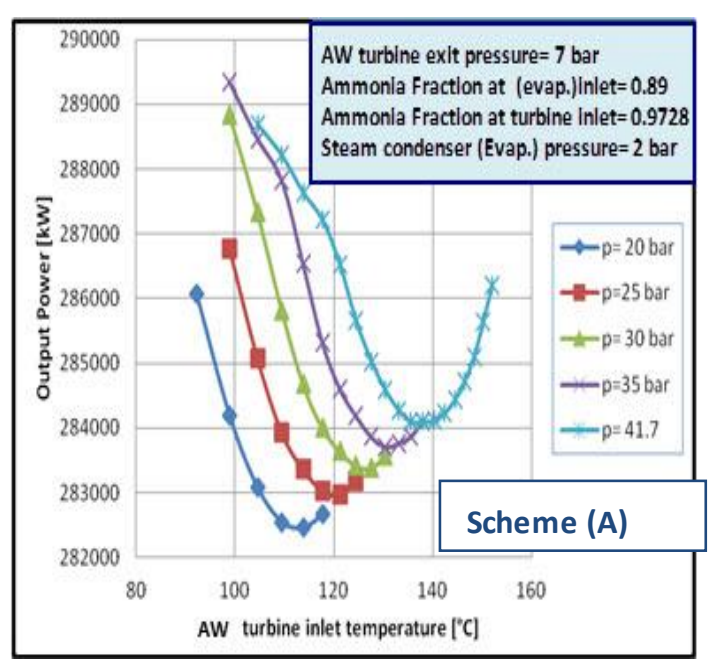

Fig.21:Effect of changing AW turbine inlet temperature on the output powerat different inlet pressures of AW turbinefor scheme (A)

Lower temperature range in Scheme (C) is higher than other schemes due to the superheating and to maintain the same temperature at heat source inlet for all schemes.

Figures (24-26) depict the variation of combined thermal efficiency with the increase of the inlet ammonia water turbine temperature at different inlet pressures of Kalina turbine.

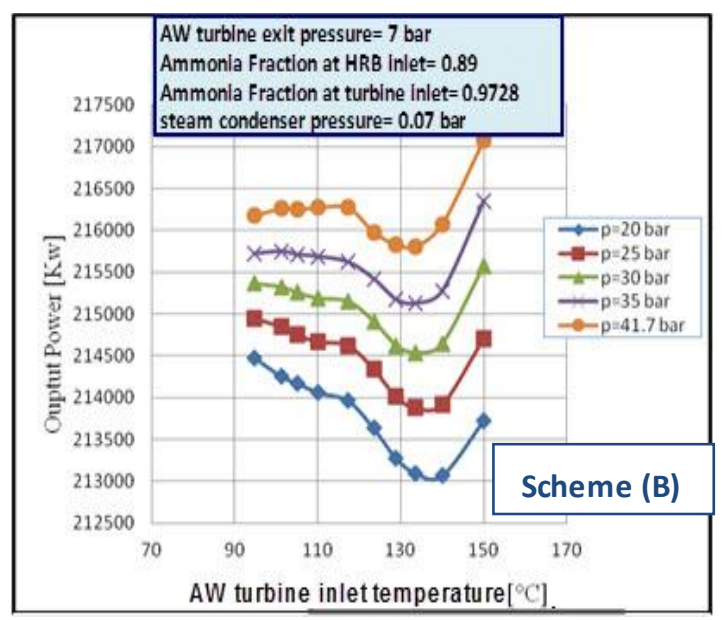

Fig.22: Effect of changing AW turbine inlet temperature on the output power at AW different inlet pressures of AW turbine for scheme (B)

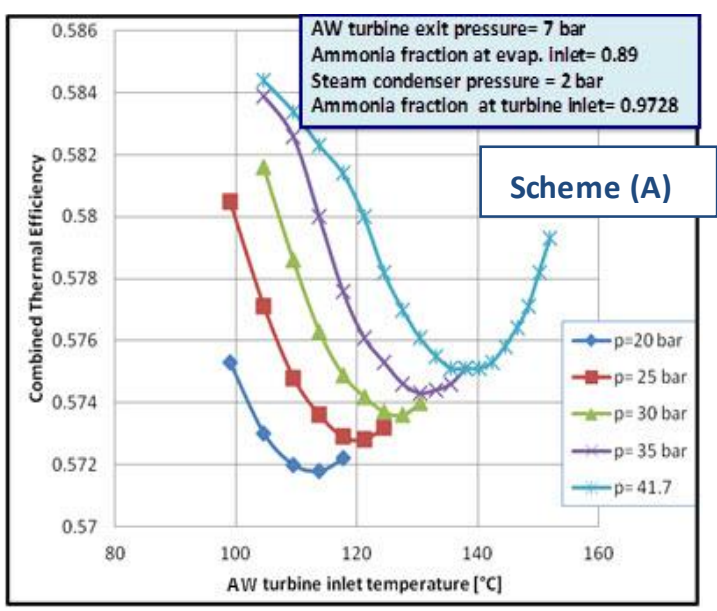

Fig.24:Effect of changing AW turbine inlet temperature on the combined thermal efficiency at different inlet pressures of AW turbinefor scheme (A)

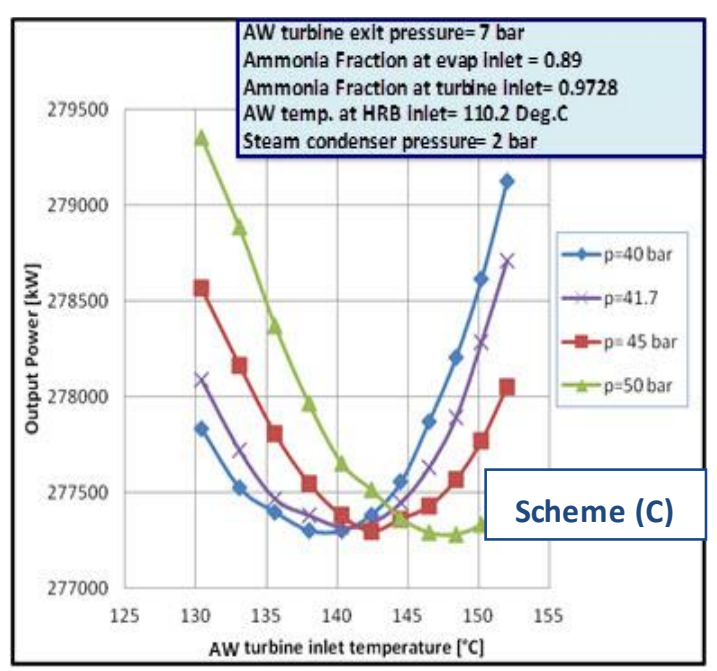

Fig.23: Effect of changing AW turbine inlet temperature on the output power at AW different inlet pressures of AW turbine for scheme (C)

In schemes (A, B), the combined thermal efficiency decreases at nearly a temperature of $95^{\circ} \mathrm{C}$ and then increases at $130{ }^{\circ} \mathrm{C}$, unlike in scheme $(\mathrm{C})$, where It is apparently seen that the efficiency decreases at a temperature of $130^{\circ} \mathrm{C}$ and then increases after $140{ }^{\circ} \mathrm{C}$ to a temperature of $150{ }^{\circ} \mathrm{C}$ due to the superheating process. 


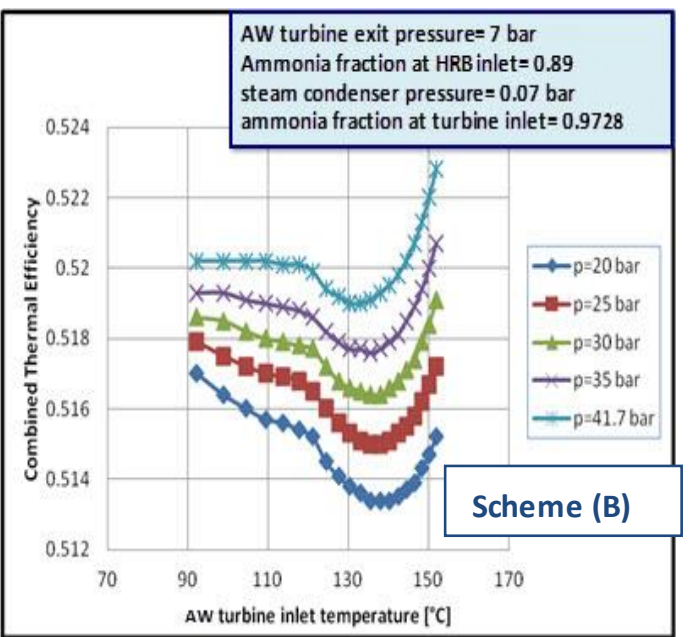

Fig.25: Effect of changing AW turbine inlet temperature on the combined thermal efficiency at different inlet pressures of AW turbinefor scheme (B)

\subsection{Effect of Ammonia Fraction at Heat Source Inlet}

Results show that the increase in ammonia fraction at heat source inlet helps in increasing the thermal efficiency. Figure 27 shows this increase for scheme (A-C), respectively. In scheme (C), it acts like scheme (A) although it has lower efficiencies than scheme (A).

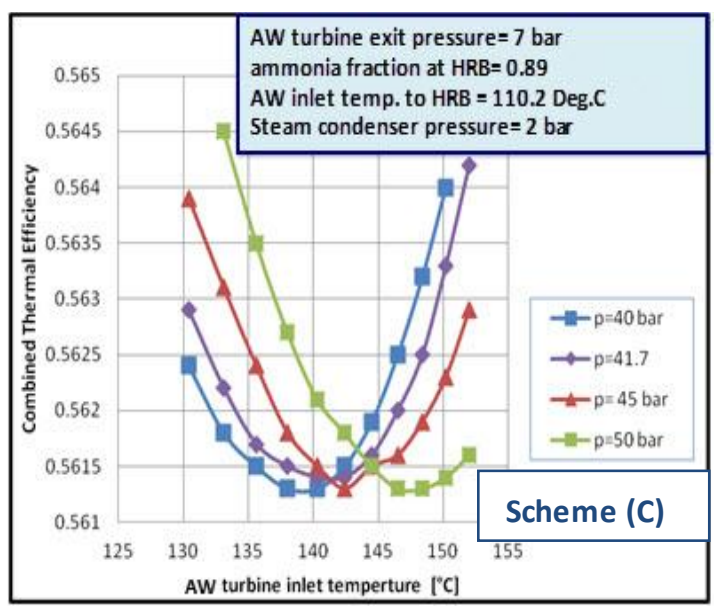

Fig.26:Effect of changing AW turbine inlet temperature on the combined thermal efficiency at different inlet pressures of AW turbine for scheme (C)

Lower efficiency is due to superheating of ammonia-water mixture, which in turn reduces the amount of heat added to the steamcycle that results in lowering the steam mass flow rate and, hence, the steam turbine power.

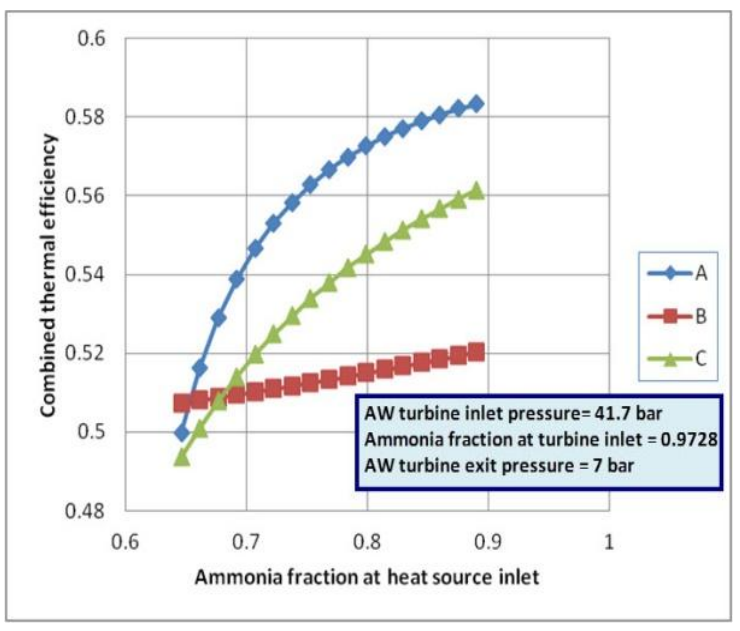

Fig.27:Effect of changing ammonia fraction at evaporator inlet on thermal efficiency for all schemes

Substantially, Scheme (A) shows a noticed improvement in power and efficiency than schemes (B) and (C). This is apparently seen in Fig.28 for the output power and in Fig.29 for the combined thermal efficiency.

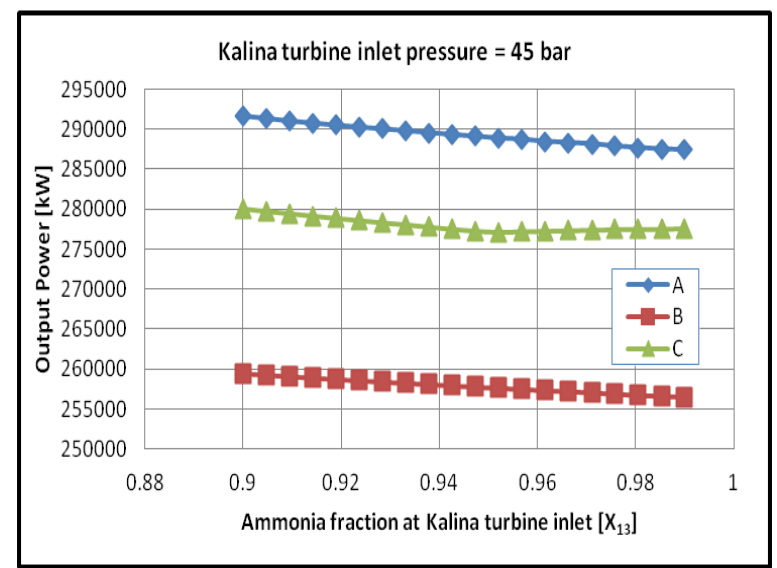

Fig.28: Power comparison at AW turbine inlet pressure of 45 bar

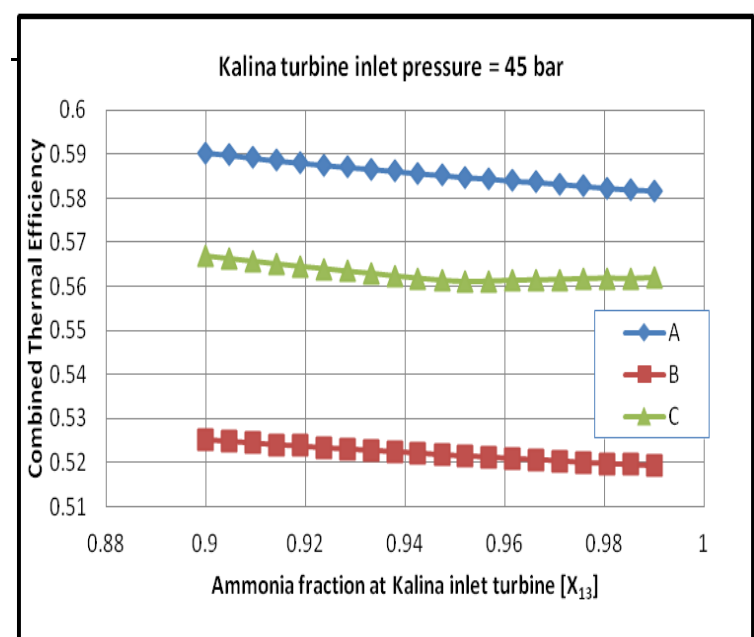

Fig.29: Efficiency comparison at AW turbine inlet pressure of 45 bar 
After studying the operating parameters of Kalina cycle on the combined cycles configurations performance, it was so necessary to calculate the specific fuel consumption for the three integrations. This Comparis on confirmed that the scheme (A) is the best choice from all the schemes as seen in Table 8 , because, it has the lower value of specific fuel consumption, higher output power, and thermal efficiency.

It is clearly noticed that, scheme (A) has the best results in thermal efficiency compared with the other schemes at the same conditions.Also the table show the superiority of scheme (A) in power and thermal efficiency.

Table 8: Performance data for the three schemes

\begin{tabular}{|l|c|c|c|}
\hline \multicolumn{1}{|c|}{ Data } & $\begin{array}{c}\text { Scheme } \\
\text { (A) }\end{array}$ & $\begin{array}{c}\text { Scheme } \\
\text { (B) }\end{array}$ & $\begin{array}{c}\text { Scheme } \\
\text { (C) }\end{array}$ \\
\hline $\begin{array}{l}\text { Specificfuel } \\
\text { consumption } \\
\text { (kg/kW.h) }\end{array}$ & 0.2019 & 0.2264 & 0.2097 \\
\hline $\begin{array}{l}\text { Output power }(\mathrm{kW}) \\
\text { Combined thermal } \\
\text { efficiency }\end{array}$ & 0.5832 & 0.5202 & 0.5618 \\
\hline
\end{tabular}

Table 9 reveals the importance of existing the Kalina cycle in the integration which increased the combined thermal efficiency with about $8 \%$ in scheme (A) and boosted the output power with nearly $40 \mathrm{MW}$.

Table 9: Performance comparison between scheme (A) with and without Kalina cycle

\begin{tabular}{|l|c|c|}
\hline \multirow{2}{*}{ Data } & \multicolumn{2}{|c|}{ Scheme (A) } \\
\cline { 2 - 3 } & $\begin{array}{c}\text { With Kalina } \\
\text { cycle }\end{array}$ & $\begin{array}{c}\text { without } \\
\text { Kalinacycle }\end{array}$ \\
\hline $\begin{array}{l}\text { Output power } \\
(\mathrm{kW})\end{array}$ & 288115 & 252635 \\
\hline $\begin{array}{l}\text { Combined } \\
\text { thermal } \\
\text { efficiency }\end{array}$ & 0.5832 & 0.5114 \\
\hline $\begin{array}{l}\text { Specific fuel } \\
\text { consumption } \\
\text { (kg/kW.h) }\end{array}$ & 0.2019 & 0.2302 \\
\hline
\end{tabular}

\section{Part Load behavior of Cascaded Combined Cycle of Scheme (A)}

It was so important to check the performance of the cycle when it operates under a part load behavior.

The computations are performed only for the higher load range of the plant with the most usual control concepts employed. So long as the plant is integrated with the electrical grid, the rotational speeds for all turbo-generators are maintained constant.

A sliding pressure control is used in HRB to affect the ST-cycle, while the live steam temperature is kept constant.

By-pass of GT exhaust gases before admitted to the boiler is the main control parameter on the performance of the combined cycle for the higher load range.

The GT-exhaust gas temperature is assumed constant thereby. At part load operation of combined cycle plant, the load is usually controlled in the higher load range on the ST-plant, while the GT-plant runs at its maximum rated output. This is to avoid large drops of the GT-plant thermal efficiency at lower loads which dramatically reduces the combined thermal efficiency.

Applying the heat transfer equation for HRB as a surface type heat exchanger involved in the plant we get:

$\mathrm{Q} \cdot=\mathrm{K} \cdot \mathrm{A} \cdot \Delta \theta_{\mathrm{m}}$

where $(\mathrm{Q})$, the rate of heat transfer, $(\mathrm{K})$ is the overall heat transfer coefficient, which remains constant along the entire length of heat exchanger and (A) is the heat exchanger surface area.

By applying the energy equation, the rate of heat transfer $\left(Q^{*}\right)$ at part load can be determined by the following analysis:

$\mathrm{Q} \cdot=\mathrm{m}_{\mathrm{st}} \cdot \Delta \mathrm{h}_{\mathrm{st}}=\mathrm{m}_{\mathrm{g}} \cdot \Delta \mathrm{h}_{\mathrm{g}}$

where $\left(\Delta \mathrm{h}_{\mathrm{st}}\right),\left(\Delta \mathrm{h}_{\mathrm{g}}\right)$ are the enthalpy change in the steam and gases respectively.

For the steam cycle, it may work in two modes: sliding pressure or fixed pressure control.

Using the Stodola cone rule, the equation is expressed as:

$m_{s t}^{*}=\sqrt{\left(p_{i}^{2}-p_{e}^{2}\right)^{*}}$

where $\left(\mathrm{m}_{\mathrm{st}}^{*}\right)$ is the relative steam mass flow rate, $\left(p_{i}, p_{o}\right)$ are the inlet and exit pressures respectively. The live steam temperature is kept constant, while the stages temperature has a slight change at variable loads. 


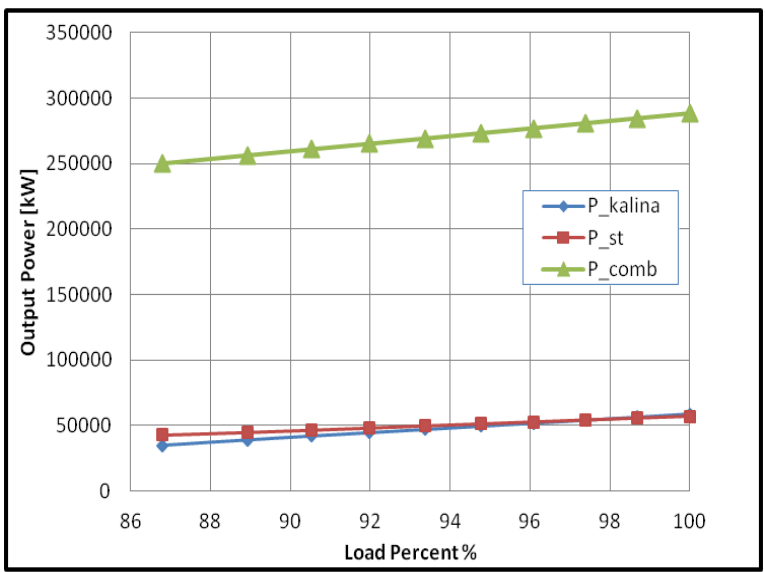

Fig.30: output power at different percentage load

The condenser temperature (and hence the pressure) at part load operation can be calculated by using the following semi- empirical formu la [16].

$\left.T_{s}^{*}=\left(\frac{T_{w o}}{T_{s o}}\right)+1 / 9\left(1-\frac{T_{w o}}{T_{s o}}\right)\left(1+8 m_{s t}^{*}\right)\right)$

where $\mathrm{T}_{\mathrm{s}}^{*}$ is the related saturation steam temperature, $\mathrm{T}_{\text {so }}$ is the design saturation steam temperature, while $\mathrm{T}_{\mathrm{wo}}$ is the design ammonia-water mixture inlet temperatures, respectively. Also, $\left(\mathrm{m}_{\mathrm{st}}^{*}\right)$ is the related condensate respectively. This simple relation makes it possible to estimate the condenser temperature and pressure for a given related mass flow rate of the condensate.

\subsection{Part Load Results for Sliding Pressure Mode}

In sliding pressure mode, the operation pressure is a direct function of the load and thus of the mass flow rate. The output power of ST- and Kalina cycles are reduced as results of lowering the exhaust gas mass

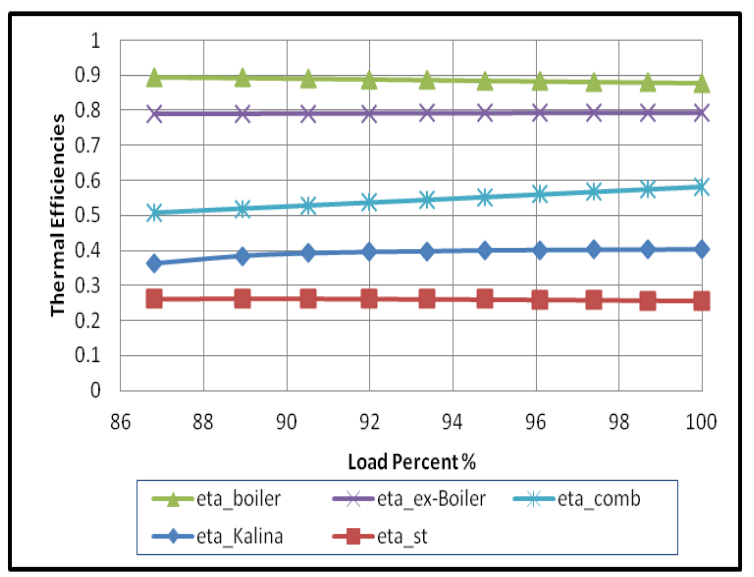

Fig. 31:Thermal efficiencies at different percentage loads

flow rate entering the HRB are shown in Fig. 30.

The steam cycle thermal efficiency, Kalina cycle efficiency, combined cycle thermal efficiency, and boiler thermal and exergetic efficiency are affected by varying the load and it can be shown in Fig. 31 that the combined thermal efficiency decreases with the load percentage reduction.

The increase in boiler efficiency is due to the decrease in stack gas temperature as seen in Fig.32 while its exergetic efficiency nearly remains constant because of the load range limit.

With decreasing the exhaust gases mass flow rate, the rate of heat input to the HRB decreases, consequently, the total steam mass flow rate also decreases in Fig. 33 and this results in increasing the ammonia-water mixture mass flow rate.

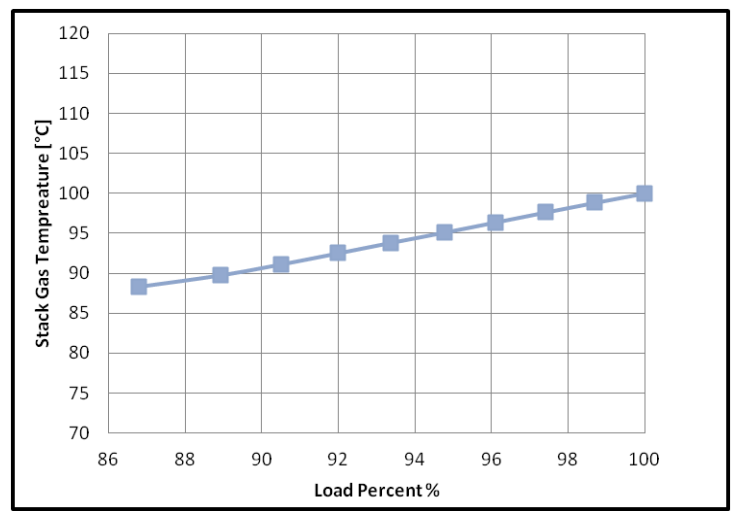

Fig.32:Stack te mperature at different percentage loads

As shown in Fig.34, it displays the variation of steam and condenser pressures at different percentage loads. The steam turbine in a combined cycle operates in a sliding pressure mode at this time; therefore, the live steam pressure changes and decreases with the load.

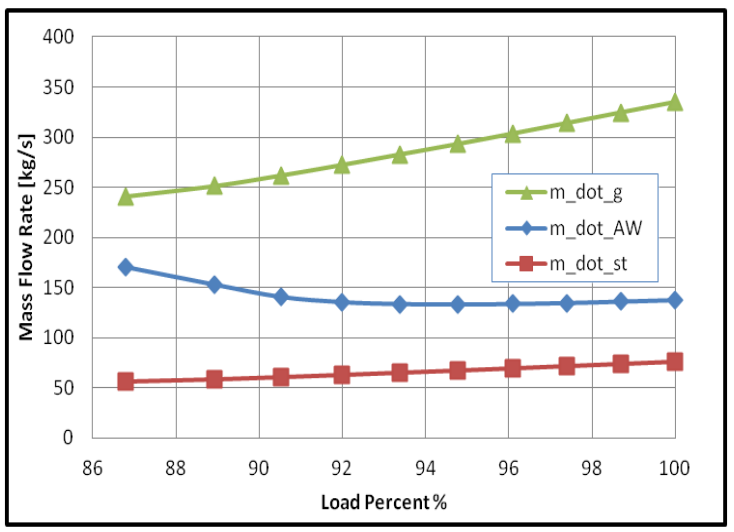

Fig.33:Mass flow rates at different percentage loads 


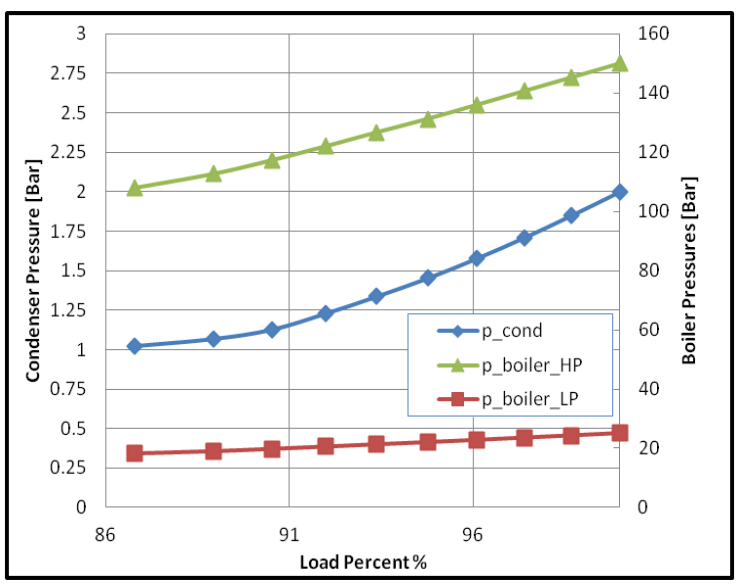

Fig.34: Pressures at different percentage loads

\section{Conclusions}

Integration of Kalina cycle with coal gasification combined cycle counterbalances the reduction of the overall efficiency due to the gasification thermal efficiency. Therefore, integration of the Kalina cycle in the ICGCC is justified.

In all the arrangements, the best combined thermal efficiency and power are obtained in scheme (A) using dual pressure HRB and cascading the Kalina cycle as the bottoming cycle.

Use of Kalina cycle in all configurations showed a contribution to the total output power and, hence, the combined thermal efficiency which increase the combined thermal efficiency with about $8 \%$ in scheme (A) and boosted the output power with nearly $40 \mathrm{MW}$.

AW turbine inlet pressure in all schemes shouldn't exceed 65 bar, otherwise, the mass of the separated lean ammonia-water mixture will fall into negative values for the specified common values of cycle constrains.

For scheme (C), Aw turbine inlet pressure can't be lower than 35 bar due to the high temperature of ammonia-water mixture at turbine inlet.

In all schemes, the boiler exergetic efficiency is high and this is a good reflection to the process of heat recovery.

Part load calculations for scheme (A) identified that the integration of Kalina cycle to ICGCC imposed restrictions to Kalina cycle constrains, so that it is more economical to keep such configurations of combined plants at nearly full load conditions.

\section{Nomenclature}

Symbol

B

cp

e

g

$\mathrm{h}$

i

$\mathrm{m}$

$m$

$\mathrm{p}$

$\mathrm{P}$

q

Q

S

$Q$

$\mathrm{t}$

$\mathrm{T}$

w

X

\section{Definition}

Boiler

specific heat $(\mathrm{kJ} / \mathrm{kg} . \mathrm{K})$

exit

Gas

Specific enthalpy $(\mathrm{kJ} / \mathrm{kg})$

Inlet

mass, make up water,

Mass flow rate $(\mathrm{kg} / \mathrm{s})$

Pressure

Power (kW)

Specific heat $(\mathrm{kJ} / \mathrm{kg})$

total heat $(\mathrm{kW})$

heat flow rate $(\mathrm{kW})$

Amount of steam ( $\mathrm{kmol})$,

separator

Temperature $\left({ }^{\circ} \mathrm{C}\right)$

Temperature $(\mathrm{K})$

Specific work $(\mathrm{kJ} / \mathrm{kg})$

Ammonia-water concentration

\section{GREEK LETTERS}

$\mu$

$\eta$

$\psi$

$\pi$

$\beta$

Mass fraction

Efficiency

Fraction of cooling air

Pressure Ratio

Fuel to air ratio

\section{SUBSCRIPTS}

a

AW

c

comb

cond

eco

evap

ex

$\mathrm{gt}$

HRB

$\mathrm{Ka}$

Mix

$\mathrm{p}$

st

sup

$\mathrm{t}$

th
Air

Ammonia-water mix

Compressor

combined cycle

condenser

economizer

evaporator

exergetic

gas turbine

Heat Recovery Boiler

Kalina

Mixing point

pump

steam

superheater

Turbine

thermal 


\section{$\underline{\text { ABBREVIATIONS }}$}

\begin{tabular}{|c|c|}
\hline $\mathrm{AW}$ & Ammonia Water \\
\hline $\mathrm{CACC}$ & Cascaded Combined Cycle \\
\hline CACSC & $\begin{array}{l}\text { Cascaded combined Cycle with } \\
\text { superheating }\end{array}$ \\
\hline CA GKCC & $\begin{array}{l}\text { Cascaded Gas turbine/Kalina } \\
\text { Combined Cycle }\end{array}$ \\
\hline EES & Engineering Equation Solver \\
\hline GT & Gas Turbine \\
\hline HPC & High Pressure Condenser \\
\hline HRB & Heat Recovery Boiler \\
\hline HTR & High Temperature Recuperator \\
\hline ICGCC & $\begin{array}{l}\text { Integrated Coal Gasification } \\
\text { Combined Cycle }\end{array}$ \\
\hline KCS & Kalina Cycle System \\
\hline LPC & Low Pressure Condenser \\
\hline LTR & Low Temperature Recuperator \\
\hline MW & Mega Watt \\
\hline NGCC & Natural Gas Combined Cycle \\
\hline ORC & Organic Rankine Cycle \\
\hline SBCC & Shared Boiler Combined Cycle \\
\hline SEP & Separator \\
\hline SFC & Specific Fuel Consumption \\
\hline SRC & Steam Rankine Cycle \\
\hline ST & Steam Turbine \\
\hline VAP & Evaporator \\
\hline WHP & Waste Heat to Power \\
\hline
\end{tabular}

\section{References}

[1] Kalina AI., Co mbined cycle system with novel bottoming cycle. ASME J Eng Gas Turbines and Power ; 106:737-742, 1984.

[2] Mlcak, H.A., "An introduction to the Kalina cycle". In proceedings of International joint power generation conference, Houston, Texas, vol.30, pp.1-11, 1996.

[3] Marston, C.H., "Parametric analysis of the kalina cycle". ASME Journal of Engineering for gas turbine and power, vol.112, pp 107116,1990

[4] Mlcak, H. A., Mirolli, M., Hjartarson, H., Husavikur, O.,and Ralph, M. "Notes from the north: a report on the debut year of the $2 \mathrm{MW}$ Kalina cycle geothermal power plants in Husavik, Iceland". Geothermal Res. Counc.Trans., 26, 715- 718, 2002.

[5] Jonsson M. Advanced power cycles with mixtures as the working fluid (Doctoral thesis). Department of Chemical Engineering and
Technology, Energy Processes, Royal Institute of Technology, Stockholm, Sweden, 2003.

[6] Pall Valdimarsson P, Eliass on L., "Factors influencing the economics of the Kalina power cycle and situations of superior performance". International Geothermal Conference, Reykjavik, pp 32-40, Sept. 2003.

[7] Hettiarachchi H., Golubovic M., Worek W. and Ikegami Y."The performance of the Kalina cycle system 11 (KCS 11) with low temperature heat sources." Journal of Energy Resource Technology, ASME, Vol.129. pp 243-247, 2007.

[8] SenthilMurugan, R., and Subbarao, P., "Effective utilization of low-grade steam in an ammonia-water cycle". Proceedings of the Institution of Mechanical Engineers,Part A: Journal of Power and Energy, 222(2), pp. 161166, 2008.

[9] Marston CH, Hyre M., "Gas Turbine Bottoming Cycles: Triple-Pressure Steam Versus Kalina", Journal of Engineering for Gas Turbines and Power;117(1):10:15, 1995.

[10] Melegy A, Salman S, "Petrological and environmental geochemical studies on the abandoned Maghara coal mine", Geolines 22:44-51,(2009).

[11] K.A.Morad, "Performance study of combined gas/steam turbine power plants utilizing coal gasification systems". Port-said,Egypt, 1987 (Master Thesis).

[12] Mikhael, N.N and K.A. Morad, "Combined cycle power plants utilizing coal gasification systems", proceeding of $6^{\text {th }}$ ICMPE, Cairo, Dec. 1986.

[13] J.H. Horlock., "Advanced Gas Turbine Cycles", 1st Edition from ISBN9780080442730, Printbook , Release Date: 2003.

[14] S. A. Klein, "Engineering Equation Solver (EES)," McGraw-Hill, 2010, http://www.mhhe.com/engcs/mech/ees/na.ht $\underline{\mathrm{ml}}$

[15] O.M.Ibrahim and S.A.Klein, "Thermodynamic properties of ammonia-water mixtures", ASHRAE Transactions:Symposia, CH-93-21$2,1993$.

[16] Dibelius, G., V. Schumacher and A. Gebhardt, " Lehrstuhl und Institute FuerDampf- Und Gasturbinen der Rhein-Westf. Techn. Hochschule Aachen", Das Teillastverhalten, KonventionellerDa mp fkraft werks blocke, WestdeutscherVerlag 1982. 